\title{
Shalfak Archaeological Mission (SAM): The 2017 field season
}

\author{
Claudia Näser, Peter Becker, Kay Kossatz, Osman Khaleel Elawad Karrar \\ with an appendix by Wolfram Grajetzki
}

\begin{abstract}
This report details the activities of the first field season of the Shalfak Archaeological Mission in April 2017. It presents the framework of the project, the results of the mapping survey, the discoveries in three excavations areas - including a hitherto unidentified Middle Kingdom extra-muros storage and/or workshop tract - as well as a reconnaissance of the fortress' surroundings. The paper also includes a short discussion of the find material recovered in this seasong.
\end{abstract}

\section{Introduction}

Only in 2002 it transpired that two of the Lower Nubian Middle Kingdom fortresses had actually survived above the waters of Lake Nubia. ${ }^{1}$ The southern one, Uronarti, became the focus of the Uronarti Regional Archaeology Project (URAP) in 2012. ${ }^{2}$ The northern one, Shalfak (N 21.541760', E $31.040600^{\circ}$ ), is preserved on a small island in Lake Nubia, $50 \mathrm{~km}$ south of the Egyptian-Sudanese border. The site, which had only seen cursory fieldwork in 1931, has now become the focus of the Shalfak Archaeological Mission. Tapping Shalfak's unique potential, this project hopes to evaluate and expand previous research into the Middle Kingdom Lower Nubian fortresses, their administrative organisation and maintenance as well was their military function and the everyday life of their occupants.

Shalfak is part of the fortification system of the Second Cataract. It is about $50 \mathrm{~km}$ south of Buhen which marks the entrance into the rough caratact area from the north. It is $10 \mathrm{~km}$ downstream of the Semna-Kumma complex which marks the southern terminus of this region and of the Egyptian control in the Middle Kingdom. The nearest fortresses from Shalfak are Uronarti, $5 \mathrm{~km}$ upstream, and Askut, $10 \mathrm{~km}$ downstream. While both Askut and Uronarti were situated on islands in antiquity, Shalfak lay on the West bank - a location it shares with $60 \%$ of the fortresses. With an enclosed area of $1838 \mathrm{~m}^{2}$ it is the smallest of the Middle Kingdom fortresses in Lower Nubia.

Much has been written about the architecture and the military functionality of the Lower Nubian fortresses, ${ }^{3}$ about their administrative ${ }^{4}$ and religious ${ }^{5}$ integration as well as about the underlying

\footnotetext{
${ }^{1}$ D. Welsby, 'Hidden Treasures of Lake Nubia', Sudan and Nubia 8 (2004), 103-4.

${ }^{2}$ C. Knoblauch and L. Bestock, 'The Uronarti Regional Archaeological Project. Final Report of the 2012 Survey', MDAIK 69 (2013), 103-42, L. Bestock and C. Knoblauch, 'Revisiting Middle Kingdom Interactions in Nubia: The Uronarti Regional Archaeological Project', Journal of Ancient Egyptian Interconnections 6 (2014), 32-5; L. Bestock and C. Knoblauch, Living Beyond the Walls: New Evidence for Egyptian Colonialism at Uronarti, Nubia, Antiquity, Project Gallery Issues 344 (April 2015) < https://antiquity.ac.uk/projgall/bestock344>.

${ }^{3}$ C. Vogel, Ägyptische Festungen und Garnisionen bis zum Ende des Mittleren Reiches (HÄB 46; Hildesheim, 2004); C. Vogel, 'Master Architects of Ancient Nubia: Space-Saving Solutions in Middle Kingdom Fortresses', in W. Godlewski and A. Łajtar (eds), Between the Cataracts. Proceedings of the $11^{\text {th }}$ Conference of Nubian Studies, Warsaw University, 27 August - 2 September 2006, Part two, fascicule 1: Session papers, (Polish Archaeology in the Mediterranean, Supplement Series 2.2/1; Warsaw, 2010), 421-430; C. Vogel, 'Storming the Gates? Entrance Protection in the Military Architecture of Middle Kingdom Nubia', in M. Bietak, E. Czerny and I. Forstner-Müller (eds), Cities and Urbanism in Ancient Egypt. Papers from a Workshop in November 2006 at the Austrian Academy of Sciences (DGÖAW 60 = Untersuchungen der Zweigstelle Kairo des Österreichischen Archäologischen Institutes 35; Vienna, 2010), 299-320, with older references.

${ }^{4}$ B. Gratien, 'Départements et institutions dans les forteresses nubiennes au Moyen Empire', in C. Berger, G. Berger and N. Grimal (eds), Hommage à Jean Leclant. Vol. 2: Nubie, Soudan, Éthiopie (BdE 106/2; Cairo, 1994),
} 
policy of the Egyptian state and the bureaucracy which came to flourish alongside this "mudbrick curtain"6. More recently, chronological considerations, primarily the question of the use of the fortresses in the Second Intermediate Period, the New Kingdom and beyond came into focus. ${ }^{7}$ Current research also tried to define the nature of this use in terms of who its agents were and whether it represented a continuous occupation or a re-occupation after a hiatus, including refortifications and an administrative and religious re-orientation. Another topic of recent studies is the lived experience of the past occupants of the fortresses. ${ }^{8}$ Enquiries into these aspects heavily depend on the quality of the original excavations and the level of detail of their documentation and publication.

The archaeological data upon which this ongoing research is based derive from three major periods of fieldwork: The first prior to World War I, the second in connection with the heightening of the first

185-97; B. Gratien, 'Les institutions égyptiennes en Nubie au Moyen Emprie d'après les empreintes de sceaux', in Actes de la VIII Conférence Internationale des Ètudes Nubiennes. Lille 11-17 Septembre 1994. I Communications principales (CRIPEL 17; Lille, 1995), 149-66; B. J. Kemp, 'Large Middle Kingdom Granary Buildings (and the Archaeology of Administration', ZÄS 113 (1986), 120-36; S. T. Smith, 'Administration at the Egyptian Middle Kingdom Frontier: Sealings from Uronarti and Askut', in T. G. Palaima (ed.), Aegean Seals, Sealings and Administration. Proceedings of the NEH-Dickson Conference of the Program in Aegean Scripts and Prehistory of the Department of Classics, University of Texas at Austin, January 11-13, 1989 (Aegaeum 5; Liège 1990), 197-219; S. T. Smith, Askut in Nubia: The Economics and Ideology of Egyptian Imperialism in the Second Millennium B.C. (SiE; London 1995); S. T. Smith, 'Sealing Practices, Literacy and Administration in the Middle Kingdom', in Le sceau et l'administration dans la vallée du Nil. Villeneuve d'Ascq 7-8 juillet 2000 (CRIPEL 22; Lille 2001), 173-94; L. V. Žabkar and J. J. Žabkar, 'Semna South. A Preliminary Report on the 1966-68 Excavation of the University of Chicago Oriental Institute', JARCE 19 (1982), 7-50. For Shalfak, see also A. L. Foster, 'Sealings from Shalfak, a Middle Kingdom fortress in Nubia', in M. Perna, Administrative Documents in the Aegean and their Near Eastern Counterparts: Proceedings of the International Colloquium, Naples, February 29 - March 2, 1996 (Turin 2000), 171-83.

${ }^{5}$ C. C. Van Siclen III, The Chapel of Sesostris III at Uronarti (San Antonio 1982); S. J. Seidlmayer, 'Zu Fundort und Aufstellungskontext der großen Semna-Stele Sesostris' III Zu Fundort und Aufstellungskontext der großen Semna-Stele Sesostris' III', SAK 28 (2000), 233-42.

${ }^{6}$ E.g. B. J. Kemp, Ancient Egypt: Anatomy of a Civilization ( $2^{\text {nd }}$ edition; London, 2006), 231-41; S. T. Smith, 'Askut and the Role of the Second Cataract Forts', JARCE 28 (1991), 107-32; Smith, Askut; S. T. Smith, 'State and Empire in the Middle and New Kingdoms', in J. Lustig (ed.), Anthropology and Egyptology. A Developing Dialogue (Sheffield, 1997), 66-89; B. B. Williams, 'Serra East and the Mission of the Middle Kingdom Fortresses in Nubia', in E. Teeter and J. A. Larson (eds), Gold of Praise: Studies on Ancient Egypt in Honor of Edward F. Wente (SAOC 58; Chicago, 1999), 435-53 (see p. 449 for the quote); Vogel, Festungen; K. Zibelius-Chen, Die ägyptische Expansion nach Nubien (TAVO 78; Wiesbaden, 1988).

${ }^{7}$ Smith, Askut; C. Knoblauch, 'Askut in Nubia: A Re-examination of the Ceramic Chronology', in K. Endreffy, and A. Bulyas (eds), Proceedings of the Fourth Central European Conference of Young Egyptologists. 31 August - 2 September 2006, Budapest (StudAeg 18; Budapest 2007), 225-38; C. Knoblauch, 'The Ruler of Kush (Kerma) at Buhen during the Second Intermediate Period: A Reinterpretation of Buhen Stela 691 and Related Objects', in C. M. Knoblauch, and J. C. Gill (eds), Egyptology in Australia and New Zealand 2009. Proceedings oft he Conference Held in Melbourne, September $4^{\text {th }}-6^{\text {th }}$ (BAR IS 2355; Oxford, 2012), 85-96. For the New Kingdom see B. G. Trigger, Nubia under the Pharaohs (London, 1976); I. Hein, Die Ramessidische Bautätigkeit in Nubien (GOF IV/22; Wiesbaden, 1991); Smith, Askut; S. T. Smith, Wretched Kush. Ethnic Identities and Boundaries in Egypt's Nubian Empire (London 2003); I. Müller, Die Verwaltung Nubiens im Neuen Reich (Meroitica 18; Wiesbaden 2013); C. Näser, 'Structures and Realities of the Egyptian Presence in Lower Nubia from the Middle Kingdom to the New Kingdom: The Egyptian Cemetery S/SA at Aniba'. In N. Spencer, A. Stevens, and M. Binder (eds), Nubia in the New Kingdom: Lived Experience, Pharaonic Control and Indigenous Traditions. (British Museum Publications on Egypt and Sudan 3; Leuven, Paris, and Bristol, 2017), 557-74.

8 Smith, Askut; S. T. Smith, 'Pharaohs, Feasts, and Foreigners: Cooking, Foodways, and Agency on Ancient Egypt's Southern Frontier', in T. L. Bray (ed.), The Archaeology and Politics of Food and Feasting in Early States and Empires (New York, 2003), 39-64; S. T. Smith, 'A Portion of Life Solidified: Understanding Ancient Egypt through the Integration of Archaeology and History, JEgH 3 (2010), 159-89; Knoblauch and Bestock, MDAIK 69; Bestock and Knoblauch, Journal of Ancient Egyptian Interconnections 6; Näser, in Spencer, Stevens, and Binder (eds), Nubia in the New Kingdom; see also the other contributions in this volume. 
Aswan Dam in the 1920s up to 1932, and the third in the framework of the UNESCO salvage campaign terminating in 1969. While all twelve Lower Nubian fortresses saw some archaeological exploration, investigations were hurried and summary in many cases, and not all data received detailed publication. Shalfak is a case in point. It was explored by Noel F. Wheeler for the Harvard University and Museum of Fine Arts Boston Expedition in four weeks, from 20 February to 21 March 1931. ${ }^{9}$ The results of this work received their final publication only in 1967 as part of the volume "Second Cataracts Forts II" by Dows Dunham which dedicated a meagre 22 pages to Shalfak. The limitations of the data thus presented are aptly summarised by the URAP investigators with regard to Uronarti which had been excavated one year before Shalfak and was published in the same volume: Uronarti, they say, was "excavated at lightning speed [... and] inadequately published 40 years after the excavation, by someone who was not involved in the original work"10.

While all research on the Nubian fortresses prior to 1970 was conducted under the premise that the sites would soon be lost, all research after that point was undertaken on the assumption that they actually had been lost. While researchers bemoaned this situation, ${ }^{11}$ they also tried to come to terms with the existing records and the inevitable element of uncertainty inherent in the attempts to answer ever-advancing questions from a painfully incomplete and epistemologically increasingly outdated database ${ }^{12}$. Contrary to the common scenario in archaeology, where practitioners usually grapple with the progressing deterioration or disappearance of their database, it is an extemely rare stroke of luck to be able to return to a site which was thought to have been lost with up-to-date methods which hold the potential to transcend the limits and uncertainties imposed on all previous enquiries by the restricted circumstances of the site's primary investigation.

The Shalfak Archaeological Mission had its first field season from 2 April to 22 April 2017. The team on the site comprised Claudia Näser (archaeologist, director), Peter Becker (architect), Kay Kossatz (archaeologist, surveyor), Osman Khalil Karar al-Awad (archaeologist), Abdelmajid Mahmoud (inspector of the National Corporation of Antiquities and Museums) and Mohamed Mohamed Eltayeb Badri (logistics). The work was funded by the Egypt Exploration Society and private donors.

\section{Mapping}

Shalfak fortress is situated at the highest point of a rocky outcrop which had formed part of the west bank of the Nile prior to the flooding, but is now a small island in Lake Nubia. According to Google Earth imagery, the size of the island varies between 180 and $280 \mathrm{~m}$ in length, and 130 and $150 \mathrm{~m}$ in width, depending on the level of the reservoir lake. The site is in a very good condition (fig. 1), largely free of modern disturbance - except for numerous droppings from sheep and goat which were herded in the shadows of the walls in the recent past. The fortification walls are still preserved to a maximum height of $8.33 \mathrm{~m}$ (see below, p. XXX). The site has not seen any archaeological activities since it was first explored by Noel F. Wheeler.

Two major tasks of this first field season were to establish a grid system and to generate an architectural plan of the fortress and the features in its immediate surrounding. This plan should illustrate the actual preservation of the monument and thus form a starting point for all future work, but also for evaluating Wheeler's plan of $1931^{13}$, upon which all subsequent research up to now had

\footnotetext{
${ }^{9}$ N. F. Wheeler, 'Harvard-Boston Expedition in the Sudan, 1930-1931', BMFA 29 (1931), 66-70; N. F. Wheeler, 'Excavations of the Harvard-Boston Expedition in Halfa Province, 1930-1931', SNR 15 (1932), 251-9.

${ }^{10}$ Bestock and Knoblauch, Journal of Ancient Egyptian Interconnections 6, 35 n. 1.

${ }^{11} \mathrm{~J}$. Vercoutter, 'Les forteresses égyptiennes du Batn-el-Haggar ou les failles d'une campagne', in Actes de la VIII Conférence Internationale des Ètudes Nubiennes. Lille 11-17 Septembre 1994. I - Communications principals (CRIPEL 17; Lille, 1995), 25-35; J. Vercoutter, 'Koummeh-Semneh. L'occasion perdue', CRIPEL 19 (1998), 35-42.

${ }^{12}$ See e.g. S. J. Seidlmayer, 'Zu Fundort und Aufstellungskontext der großen Semna-Stele Sesostris' III', SAK 28 (2000), 242.

${ }^{13}$ Published in D. Dunham, Second Cataract Forts II: Uronarti, Shalfak, Mirgissa (Boston, 1967), map X.
} 
been based. Thirteen fix points were marked on the site, and a total of 2800 measurement points was taken, covering an area of $3766 \mathrm{~m}^{2}$. The resulting plan (fig. 2) reproduces the wall courses at the extant surface level; only in some places recent accumulations of windblown sand had been removed to clarify corners of rooms and edges of walls. A comparison with the 1931 documentation shows that Wheeler's plan is indeed schematic and idealised, incorporating details which are not matched by the record on the ground. Thus, the 2017 plan is a seminal foundation for the upcoming architectural analysis as well as for the following condition mapping and monitoring.

The data collected in the mapping survey also allow the three-dimensional representation of the main architectural features of the fortress (fig. 3). The maximum extension of the fortress is $80.7 \mathrm{~m}$ in length and $51.2 \mathrm{~m}$ in width. The maximum wall thickness is $7.67 \mathrm{~m}$ in the area of South Wall West. The distinctive buttresses which structure the outer faces of the enclosure wall and feature prominently in Wheeler's photographs ${ }^{14}$ are almost invisible at surface level today (figs $2-3$ ). On the one hand, this is due to the fact that Wheeler had the debris of the excavation in the fortress' interior dumped over the extant outer walls, thus burying the bases of their external faces. On the other hand, wall portions which had not been covered in this way suffered from extensive erosion. This is particularly severe along West Wall and West Wing which are exposed to the prevailing strong northwesterly winds. Part of West Wing was cleared from windblown sand and surface rubble to record its extension and construction details - and displayed this phenomenon acutely. In contrast, the best preserved wall portion is South Gate East, with a standing height of up to $8.33 \mathrm{~m}$ (fig. 3).

\section{Architectural survey}

Alongside the mapping, a detailed architectural survey was started which aims to offer further insights into the building history of the fortress as well as into the technologies and techniques employed in its construction and maintenance. For the sake of clarity, Wheeler's designations of the main architectural elements were retained (figs 2-3). This concerns the numbering of the main building units (Blocks I to VII) and the names of the passages in the fortress' interior ('streets'), the fortress enclosure walls (West Wall, North Wall, East Wall North, East Wall South, South Wall), the spur walls (West Wing, East Wing, North Wing) and the gates (South Gate, North Gate). The individual room numbers were also adopted, altough adaptations may be necessary - as already the first excavation has shown (see below 4.1.). The fortress is oriented Southwest-Northeast. However, following Wheeler, the ideal orientation of 'river North' is used in the verbal descriptions and indicated in all plans along with 'magnetic North'.

\subsection{General observations}

The walls of the fortress are massive mudbrick constructions. Brick sizes vary from 31.0 to $33.5 \mathrm{~cm}$ in length, 16.0 to $17.5 \mathrm{~cm}$ in width, and 9.0 to $10.0 \mathrm{~cm}$ in height. Block II is differentiated from the other buildings in the fortress' interior by the partial employment of mudbricks with a distinctively lighter colour and coarser aggregates (fig. 1). Isolated bricks of this type also appear in other contexts, e.g. in the wall which delineates North Wing Street, i.e. the pathway south of the North Wing Wall, towards south (see below 4.1).

The sequence of construction has not yet been studied in detail, but the overall rarity of joints in the outer curtain and wing walls indicates that large wall portions were erected in one go, instead of joining smaller segments. With regard to the fortress interior: Blocks I and II display conspicuously stronger walls (fig. 2) which suggest that they a) represent the most important buildings, and b) were the first units erected in the interior space. They occupy about $48 \%$ of the built-up area (fig. 2). Block I comprises the granary and a suite of rooms (7-9), whose function was further explored in this

\footnotetext{
${ }^{14}$ Dunham, Uronarti, Shalfak, Mirgissa, pls L.A, L.B, LIII.A.
} 
season (see below 4.3.). Block II contains the command building (fig. 1). Block VII holds the barracks, whereas Blocks III to VI are less obvious in their function.

\subsection{Organic building materials}

A special feature of the Middle Kingdom Nubian fortresses is the lavish use of organic building materials, namely wood and matting, which were inserted into the mudbrick walls. While the evidence of the fortresses has triggered substantial research into individual architectural elements and their function, limited attention has been given to the building materials proper. ${ }^{15}$ At Shalfak, organic materials are preserved exceptionally well (figs 4-6), ${ }^{16}$ offering a unique opportunity to further study this aspect of Pharaonic monumental architecture.

\subsubsection{Wood}

In Shalfak, logs were embedded transversely into all curtain walls and South Gate at regular intervals (figs 4-5). The only instance inside the fortress is in Block II, namely the wall which incorporates the staircase (fig. 2). With a thickness of $3.6 \mathrm{~m}$ it is much stronger than any other interior wall. A similar use of building timber was noted in the fortresses of Ikkur ${ }^{17}$, Quban ${ }^{18}$, Serra East ${ }^{19}$, Mirgissa ${ }^{20}$, Uronarti ${ }^{21}$, Semna ${ }^{22}$ and Kumma ${ }^{23}$. At Shalfak, the logs are not worked and mostly still carry their bark (fig. 4). Many of them are rather crooked, which complicated the placement of the surrounding brickwork. All examined instances show a very careful execution. While the trunks seem well preserved on a macroscopic level, first botanical analyses indicate that the organic structure has widely disintegrated, while the material was extremely hardened by resins or other fluids. This makes it difficult to recognise the characteristic microstructures needed for species identification. Sample preparation by carbonisation, however, allowed a general identification as Acacia $s p .{ }^{24}$

A second kind of timber used in the construction were beams with a roughly square section. In Shalfak, these logs often preserve the curving of the original trunks and are only roughly trimmed (fig. 12). In some instances the tool marks, probably from adzes, are still visible. In Shalfak, such square section logs occur in several positions. Negative spaces of mostly decayed timber with a minimum of five rows of beams set at intervals of three to four brick courses of bricks are preserved at South Wall East in the area where the eastern tower of South Gate was added (fig. 2). An excavation in the area where North Wing Wall abuts North Wall West exposed the southernmost niche of North Wing Wall (fig 2). This niche has beams inserted horizontally in the surface of the brickwork on all three sides (fig. 12). They are embedded after every third brick course, resting on beams inserted along the face of North Wall in the same manner. Whether these beams were interlocked or anchored in the surrounding brickwork in any way or were simply placed amidst the bricks remains to be ascertained. Again, similar features are present at other fortresses, such as Serra East $^{25}$, Uronarti ${ }^{26}$ and Semna ${ }^{27}$.

\footnotetext{
${ }^{15}$ See Vogel, Festungen, passim, with further references.

${ }^{16}$ This is in partial contrast to Uronarti, where only the "negative space and occasionally the bark" of the tree trunks remain; cf. Knoblauch and Bestock, MDAIK 69, 141.

${ }^{17}$ C. M. Firth, The Archaeological Survey of Nubia. Report for 1908-1909. Vol. 1 (Cairo, 1912), $23-4$.

${ }^{18}$ W. B. Emery, and L. P. Kirwan, The Excavations and Survey between Wadi es Sebua and Adindan 1929-1931. Vol. 1: Text (Cairo, 1935), 30.

${ }^{19}$ G. Hughes, 'Serra East: The University of Chicago Excavations, 1961-62: A Preliminary Report on the First Season's Work', Kush 11 (1963), 124.

20 Dunham, Uronarti, Shalfak, Mirgissa, 156-7.

${ }^{21}$ Dunham, Uronarti, Shalfak, Mirgissa, 21-22.

${ }^{22}$ D. Dunham and J. M. A. Janssen, Second Cataract Forts I: Semna, Kumma (Boston, 1960), 5-6.

${ }^{23}$ Dunham and Janssen, Semna, Kumma, 114.

${ }^{24}$ The archaeobotanical analyses were conducted by Stephanie Darius-Nussbaum and Frank Darius, Berlin.

${ }^{25}$ Hughes, Kush 11, 125.
} 
Even this first reconnaissance of the Shalfak evidence indicates that an immense amount of wood was used in the construction of the Nubian fortresses. While first analyses show that locally available species were employed, it remains a task for the next seasons to learn more about the procurement of this material and its integration in the building processes.

\subsubsection{Matting}

The second organic material which was used in the construction of the fortresses in copious amounts was matting. Like the tree trunks, mats were inserted in the walls in regular intervals. The feature has also been reported from the fortresses of Ikkur ${ }^{28}$, Quban ${ }^{29}$, Serra East ${ }^{30}$, Mirgissa ${ }^{31}$, Uronarti ${ }^{32}$, Semna ${ }^{33}$ and Kumma ${ }^{34}$ as well as the linear defense system in the First Cataract. ${ }^{35} \mathrm{~A}$ first recording at Shalfak revealed mats to be present in all curtain walls as well as in the walls of Blocks I and II. ${ }^{36}$

In the curtain walls mats are inserted every ten to thirteen brick courses. In East Wall, four layers of mats were recorded with the highest being $4.6 \mathrm{~m}$ above the ancient street level. In West Wall, which is preserved up to $3.3 \mathrm{~m}$ above the modern surface on the inner face, one layer is present. The same goes for South Wall of which only a few courses of brick remain. The west tower of South Gate has four layers. In Blocks I and II, mats are incorporated in the outer walls. They are also present in the inner walls of Block I which are the heaviest inner walls in the fortress, aside from the staircase wall in Block II.

The preservation of the mats is generally very good (fig. 6). Often, the manufacturing techniques, the layout of the weaving and the stitching are clearly recognisable. In the current season, five samples of matting were collected for further analysis. The majority of the matrix material from these was identified as Desmostachya bipinnata, one of the two most common Halfa grasses of the Nile flood plain in the northern Middle Nile valley. ${ }^{37}$ Cyperaceae, i.e. sedges, were present in small quantities. Whether they formed intentional inclusions in the mats remains to be ascertained. While it can assumed that both plants were present in the vicinity of Shalfak, it can of course not be excluded that the mats were produced elsewhere and imported to the site. Particularly Demostachya bipinnata has been frequently used in basketwork in the Nile valley since antiquity. ${ }^{38}$ Based on these first results, a refined sampling strategy is currently being developed for future investigations.

${ }^{26}$ G. A. Reisner, 'Ancient Egyptian Forts at Semna and Uronarti', BMFA 27 (1929), fig. 7; Dunham, Uronarti, Shalfak, Mirgissa, 21-22.

27 Dunham and Janssen, Semna, Kumma, 5-6, pl. 4.B; Dunham, Uronarti, Shalfak, Mirgissa, pl. VI.A. Cf. Dunham, Uronarti, Shalfak, Mirgissa, pls L.A, L.B, LIII.A for Shalfak. Several of these images show that the walls in question had been plastered, with the wood disappearing from view.

${ }^{28}$ Firth, ASN 1908-1909. Vol. 1, 23-4.

${ }^{29}$ Emery, and Kirwan, Excavations and Survey, 30.

${ }^{30}$ Hughes, Kush 11, 124.

${ }^{31}$ Dunham, Uronarti, Shalfak, Mirgissa, 156.

32 Dunham, Uronarti, Shalfak, Mirgissa, 21.

${ }^{33}$ S. Clarke, 'Ancient Egyptian Frontier Fortresses', JEA 3 (1916), 178. The mats are not mentioned in the reports of the excavators and in Dunham and Janssen, Semna, Kumma.

${ }^{34}$ Dunham and Janssen, Semna, Kumma, 114.

${ }^{35} \mathrm{H}$. Jaritz, 'The investigation of the ancient wall extending from Aswan to Philae. First preliminary report', MDAIK 43 (1986), 71, fig. 4, pls 37b, 38c; H. Jaritz, 'The investigation of the ancient wall extending from Aswan to Philae. Second preliminary report', MDAIK 49 (1993), 113.

36 These findings correct Dunham's (Uronarti, Shalfak, Mirgissa, 121) statement that mats are absent at Shalfak. L. Borchardt, Altägyptische Festungen an der zweiten Nilschnelle (Leipzig, 1923), 11.

${ }^{37}$ The other being Imperata cylindrica.

${ }^{38}$ R. Germer, Flora des pharaonischen Ägypten (SDAIK 14; Mainz a.R., 1985), 202; W. Wendrich, The World According to Basketry. An Ethno-archaeological Interpretation of Basketry Production in Egypt (CNWS Publication 83; Leiden, 1999), 147-8, 282-3; W. Z. Wendrich, 'Basketry', in P. T. Nicholson and I. Shaw (eds), Ancient Egyptian Materials and Technology (Cambridge, 2000), 255. 


\subsubsection{The function of the organic building materials}

Several authors have commented on the use of timber and matting in the brickwork of the Nubian fortresses. But despite the prominence of these features, they have never been studied in detail. Carola Vogel summarily describes them as "measures to disperse and dissipate the tremendous compressive force" of the mudbrick walls. ${ }^{39}$ In contrast, Reisner assumes that "these beams and logs made the undermining or the penetration of the walls a very labourious and indeed a practically impossible process"..$^{40}$ He thus regards them less as a static necessity than a measure to improve the defensibility. Somers Clarke suggests that the timber was to "to bind together the great semi-plastic masses of brickwork", while "the object of these mats was to check the tendency of the bricks to move or spread in the still soft mortar". ${ }^{41}$

The labour- and material-intensive use of the two materials suggests that they were of immediate concern for the functionality of the walls. As wood and matting often occur together - although no logs were mentioned for the linear defense system in the First Cataract - they should also be analysed together. From a statics point of view, the dimensions of the fortress walls would indeed have caused structural problems. During drying, large bodies of moist material, such as mud or concrete, shrink. Without an appropriate reinforcement, shrinkage cracks would be inavoidable and could eventually lead to a breaking-up of the brickwork and the collapse of the wall. The transverse logs and the mats would have acted as tension anchors, much in the same way as steel reinforcements in present-day concrete constructions, which absorb the tensile stresses resulting from shrinkage. ${ }^{42}$ Obviously, measures to prevent the negative impacts of shrinkage were applied in a differentiated way. In Shalfak, timber was only used in walls thicker than $3.6 \mathrm{~m}$. In contrast, mats appear in walls with a minimum width of $1.54 \mathrm{~m}$. In this context it should be noted that the combination of cross beams and matting was not developed in the context of the Nubian fortresses, but is already present in the Third Dynasty mudbrick town wall of Elephantine. ${ }^{43}$ Thus it represents a constructional measure and a building technique which considerably predates the Middle Kingdom.

\section{Excavations}

In the current field season, three excavation areas were opened. They were specifically placed to supplement the mapping and the architectural survey as well as start investigations into the religious and economic workings of the fortress.

\subsection{Excavation Area 1: The Northeast Annex}

The largest excavation, in all $153 \mathrm{~m}^{2}$, covered the area north of the fortress, outside North Gate (figs $2,7)$. This is the location where a sacral complex is situated in Uronarti. Under reference to that finding, Carola Vogel ${ }^{44}$ had suggested that the building discovered by Wheeler in this locale may also have been part of a cult installation, for which no space was available in the fortress proper. As Wheeler's documentation was very superficial and a temple is so far missing at Shalfak, a reinvestigation ranked high on the list of priorities.

\footnotetext{
${ }^{39}$ C. Vogel, The fortifications of Ancient Egypt 3000-1780 BC (FORTRESS 98; Oxford, 2010), 19. Cf. Vogel, Festungen, 120.

${ }^{40}$ Reisner, BMFA 27, 69. Repeated by Dunham and Janssen, Semna, Kumma, 6 without indication of the source.

Along the same lines, Borchardt, Altägyptische Festungen, 30-31.

${ }^{41}$ Clarke, JEA 3, 178.

${ }^{42}$ We thank Dipl.Ing. Volker Link for consultations on this aspect.

${ }^{43} \mathrm{M}$. Ziermann, Elephantine XVI: Befestigungsanlagen und Stadtentwicklung in der Frühzeit und im frühen Alten Reich (AVDAIK 87; Mainz a.R., 1993), 131.

${ }^{44}$ Festungen, 142.
} 
According to Wheeler, the area had been taken up by a building complex comprised of four rooms (84-87) whose outline follows the course of North Wall East and the northern spur wall, i.e. North Wing Wall. ${ }^{45}$ The layout of this complex as reproduced in the published plan does not give any indication as to its function. The locale also contained the so-called "stone slab bath", an installation "with the remains of channels entering it from the four cardinal points, similar to those found at Semna and Uronarti". ${ }^{46}$ Similar installations have been recorded in Serra East, Mirgissa, Uronarti, Kumma, Semna and Semna South. They triggered a wide range of interpretations, starting from a ritual purpose, a use as libation or ablution place, up to an understanding as a technical installation, i.e. a wine press, a metal smelting place or a gold washing station. ${ }^{47}$ Our return to Shalfak offered the opportunity to actually re-investigate one of these installations and its surroundings.

The current investigation concerned the area of Rooms 85 and 86 as well as large parts of Room 87 . Prior to the excavation, scant traces of mudbrick walls were visible on the surface. A test trench revealed well-preserved mudbrick structures the course of which did, however, not conform to the published plan. The comprehensive clearing eventually uncovered a suite of three rooms (provisionally labelled $85 \mathrm{~A}, \mathrm{~B}$ and $\mathrm{C}$ ), instead of the two rooms $(85,86)$ mapped by Wheeler. The shallow remains provided evidence for a dense building sequence (fig. 8) which included several adjustments of the architectural substance - all of which seem to date to the Middle Kingdom. The following phases could be differentiated:

1. The wall bordering the complex to the west was built (fig. 8: phase 1). It actually is the wall which delineates North Wing Street, i.e. the pathway east of the North Wing Wall, towards east. This wall is two bricks wide and aligns with the brick pavement of North Wing Street. It is therefore reasonable to assume that it was part of the primary layout of the fortress. After this, the outlines of the threeroom structure were built against the east face of this wall (fig. 8: phase 1). The rooms were accessed through a doorway from North Wing Street. As also this doorway was part of the primary construction of North Wing Wall, it can be argued that the suite of rooms was planned with the original layout. No doorways between the three rooms are preserved and it remains uncertain how they were interconnected. Remains of plaster along several walls and the entrance from North Wing Street and on the floors indicate that both, the walls and the floors had originally been plastered (fig. 8). Underneath the plaster floor, a floor of mudbricks is preserved (fig. 8). The bricks had been laid in a right angle in Rooms $85 \mathrm{~A}$ and $85 \mathrm{C}$, whereas they were aligned with the course of the walls in the middle Room 85B.

2. In the next step, two walls were built separating off two narrow spaces against the eastern walls of the second and the third room from the east (Rooms 85A, B; fig. 8: phase 2).

3. At some point later, the rear parts of the three rooms and the original entrance were blocked with a construction consisting of a wall, one and a half bricks wide and mainly laid in rowlocks, aligning a space filled with rubble and chunks of bricks and stones (fig. 8: phase 3). The function of this construction is unclear. Current evidence suggests that there was no built-up of sediments in the rooms before the blocking was introduced. This as well as the similarity of the brick material suggests that the blocking is chronologically close to the primary construction of the rooms and dates to the Middle Kingdom.

4. A later phase of use is present in a fireplace in Room $85 \mathrm{~A}$ (fig. 8). As it partly obscures the surfaces of the bricks preserved nearby, it must have been introduced when the wall had already decayed to its current level. The feature may chronologically correspond with another, much smaller fireplace in the open space north of the rooms (fig. 8). Near the latter, the rim sherd of a ledge-rim bowl was found, and a rim sherd of another ledge-rim bowl comes for the general surface clearing of the area.

\footnotetext{
${ }^{45}$ Dunham, Uronarti, Shalfak, Mirgissa, map. X.

${ }^{46}$ Dunham, Uronarti, Shalfak, Mirgissa, 120, cf. also Dunham, Uronarti, Shalfak, Mirgissa, pl. LIII.B, map X.

47 See Vogel, Festungen, 142-4 and K. Liszka, 'Water Basins in Middle Kingdom Planned Settlements', in V. Gashe, and J. Finch (eds), Current Research in Egyptology 2008. Proceedings of the Ninth Annual Symposium (Bolton, 2008), 51-68 with further references, also of the individual occurences in the other Nubian fortresses.
} 
Even with the complete processing of the pottery pending, these finds indicate that the area saw human activity in the Medieval period. This assumption is further substantiated by two decorated bowls which were found by Wheeler in the same general area, i.e. "northwest of fort" ${ }^{48}$ Their decoration, colour scheme and vessel shape indicate a date in the Late Christian Period (1100-1400 AD). ${ }^{49}$ The Medieval activities in this area cannot be connected to any architectural installations or stratigraphic contexts with the possible exception of the two fireplaces. ${ }^{50}$ That this re-use did not observe the older mudbrick structures suggests that they had already substantially decayed by this time.

Another feature was an accumulation of what seems to be trampled droppings of animals, abutting the north wall of Rooms 85A (fig. 8). Its extension suggests that it dates from a period when the wall was still a standing structure - whether this was during the Middle Kingdom remains, however, speculative.

As Excavation Area 1 is open to the predominant winds from the northwest, the stratigraphy was very shallow and the mudbricks were much eroded (fig. 7), making the recording and analysis of the evidence challenging at times. The Middle Kingdom architecture was only covered by a thin layer of accumulated sand and mixed with chips and chunks of local stone and pot sherds. It is unclear whether Wheeler had cleared the site completely and the layer represents a recent accumulation. Images taken during his season indicate that also in 1931 the deposit on the crest and the eastern side of the hill was very shallow. ${ }^{51}$ Thus, it came as a complete surprise when the excavation revealed the remains of a mudbrick floor (fig. 8) which had apparently completely covered the area north of Rooms $85 \mathrm{~A}$ to $\mathrm{C}$ in antiquity. So far, it was only exposed in some places, but more traces of it may emerge in the coming season. This finding sheds new light on the final feature which remains to be discussed in this context: the "stone slab bath" in the northern part of the excavated area (figs 2-3, 8-11).

Even though no direct link could be established it seems that the basin had once been sunk into the mudbrick floor and formed part of the primary development of the area. Its immediate surroundings were severely disturbed (figs 9). The casings of the inlet channels and the pottery vat from the central depression had been removed. ${ }^{52} \mathrm{~A}$ number of thick-walled sherds which were scattered in the vicinity may represent fragments of the latter. The fill of the central depression was of recent date, containing pieces of cigarette packs and matchboxes, which attested to repeated disturbances. While this deprived us of the chance to re-document the feature in its primary condition, we could still study the structural remains. The basin had a maximum diameter of $c .1 .1 \mathrm{~m}$ and a depth of $c .0 .96$ $\mathrm{m}$ (figs 8,10 ). Its walls tapered towards the bottom with one clearly defined step, at a height of 0.64 $\mathrm{m}$ from the deepest point, where the diameter narrowed to $0.76 \mathrm{~m} .{ }^{53}$ This step would have equalled the upper end of the pottery vat. ${ }^{54}$ The walls of the pit had been smoothed with mud plaster into which small chunks of stone had been pressed (figs 10-11), presumably to fill voids before the vessel

\footnotetext{
48 Dunham, Uronarti, Shalfak, Mirgissa, 131, fig. 6. Both vessels are today in the MFA Boston, 47.1672 and 47.1673. Wheeler himself assumed "a short and unimportant occupation in the Meroitic period" (Wheeler, BMFA 29, 70).

${ }^{49}$ See W. Y. Adams, Ceramic Industries of Medieval Nubia. 2 vols (Memoirs of the UNESCO Archaeological Survey of Sudanese Nubia 1, Parts I and II; Lexington, Kentucky, 1986), fig. 189: element E9-5, for the border frieze on the bird bowl, Adams Ceramic Industries, figs 197-8, 203 for the filled triangles in the corner of other elements, and Adams, Ceramic Industries, figs 203-4 for the hatched geometric motifs. According to Adams, Ceramic Industries, fig. 239, bird motifs run from the Classic to the Late Christian Period. Both bowls probably belong to Adams' ware R11; see Adams, Ceramic Industries, 504-5.

${ }^{50} 14 \mathrm{C}$ dating of charcoal samples from these contexts is pending.

${ }^{51}$ Dunham, Uronarti, Shalfak, Mirgissa, pls L.B- LI.A.

${ }^{52}$ For an earlier state see Dunham, Uronarti, Shalfak, Mirgissa, pl. LIII.B.

53 These measurements correct the figures given by Liszka, in Gashe, and Finch (eds), Current Research, 52-3.

${ }^{54}$ Dunham, Uronarti, Shalfak, Mirgissa, pl. LIII.B indicates that the vessel was about $0.75 \mathrm{~m}$ deep. This would indicate that the level of the step had been raised with stone slabs and mortar by about $10 \mathrm{~cm}$.
} 
was put in place. The irregularity of the pit precludes that the vat had straight walls down to the bottom of the pit.

As stated above, similar installations came to light in six other fortresses. One basin was recorded at Uronarti in a large open space in the Northwest Annex..$^{55}$ The basins in Semna West ${ }^{56}$ and Kumma ${ }^{57}$ are situated in the largest rooms of workshop and storage tracts. Three basins at Mirgissa lie in a poorly preserved and defined area. ${ }^{58}$ The contexts of the basins in Serra East and Semna South are too incompletely recorded and published to allow a meaningful interpretation. ${ }^{59}$

The overall context of the Shalfak basin resembles that of the Northwest Annex in Uronarti, as a large open extra muros space, bordering the minor gate into the fortress. The non-rectangular layout of Rooms $85 \mathrm{~A}$ to $\mathrm{C}$ in Shalfak finds a parallel in the buildings in the Southeast Sector at Askut which were interpreted as storage and workshop rooms. ${ }^{60}$ They are also situated extra muros, but in this case near the main gate. Askut most clearly presents the layout of such a tract, which has only been partly revealed at Shalfak so far.

As far as the diameters of the basins could be ascertained they ranged from 1.1 to $1.6 \mathrm{~m}$. About their depths, less information is available, but two basins at Mirgissa $(A)$ and Semna West were c. 0.8 and $0.7 \mathrm{~m}$ deep. ${ }^{61}$ Three basins in Mirgissa (A), Semna West and Kumma still contained pottery vessels. ${ }^{62}$ A floor "originally paved with burnt-brick tiles" was recorded at Mirgissa. ${ }^{63}$

The functional interpretation of the Southeast Sector at Askut - and its transfer to the Shalfak evidence - connects the Shalfak basin with the occurences of similar installations in the largest rooms of intra muros storage and workshop tracts. Drawing all data together we can conclude that these basins were connected with spacious activitiy areas which were related to storage and workshop tracts. This effectively puts to rest their interpretation as libation places, which had primarily been derived from the spatial proximity of the basins to the chapel areas in Uronarti and Kumma ${ }^{64}$ The findings and comparisons clearly define the Northeast Annex at Shalfak as a storage and/or industrial complex, with no evidence of a sacral installation. ${ }^{65}$

The structural properties indicate that the basins were intended to collect a liquid. ${ }^{66}$ They may have been connected with ablutions as suggested by Dunham and Janssen a propos Semna and Kumma. ${ }^{67}$ But they could also have been used to collect another liquid, e.g. blood after butchering, or store a content that needed to be kept in water, e.g. fish. As so far no food processing has been demonstrated for the quarters in which basins were found, these possibilities remain speculative. The interpretive advances which the newly recorded evidence at Shalfak offers is that we can plausibly connect the basin there with the first building phase of the Northeast Annex, confirming its

\footnotetext{
${ }^{55}$ Dunham, Uronarti, Shalfak, Mirgissa, 14, map III. Contra Vogel, Festungen, 143 there is no indication that this basin is on a New Kingdom level.

${ }^{56}$ Janssen and Dunham, Semna, Kumma, 8, pI. VIII.C, D, maps IV, XII.

57 Janssen and Dunham, Semna, Kumma, 115, map XVI.

${ }^{58}$ G. A. Reisner, 'The Egyptian Forts from halfa to Semna', Kush 8 (1960), pl. XII.B; Dunham, Uronarti, Shalfak, Mirgissa, 144, pl. LXXVII.B, map XVII.

${ }^{59}$ Hughes, Kush 11, 126-7, plan II, pI. XXXI.b and Žabkar and Žabkar, JARCE 19, 11. The latter specimen as well as the basin in Shalfak are missing from the discussion of Liszka, in Gashe, and Finch (eds), Current Research.

${ }^{60}$ Smith, Askut, passim, e.g.figs 3.3., 3.13.

${ }^{61}$ For Mirgissa, basin A, see Dunham, Uronarti, Shalfak, Mirgissa, 144. For Semna, see Janssen and Dunham, map XII.

62 Dunham, Uronarti, Shalfak, Mirgissa, 8, 115, 144.

63 Dunham, Uronarti, Shalfak, Mirgissa, 144.

${ }^{64}$ In both cases a temporal correlation between the basin and the sacral complex cannot be demonstrated and is questioned by the current authors, not least on the ground of the evidence discussed here.

${ }^{65}$ Contra Vogel, Festungen, 142.

${ }^{66}$ Not least missing traces of heat exposure make their interpretation as kilns unlikely; contra Vogel, Festungen, 244.

67 Janssen and Dunham, Semna, Kumma, 8, 115.
} 
Middle Kingdom date, and rule out a sacral use through the identification of the associated building complex as a storage and/or production space.

The exploration of Excavation Area 1 could not be completed this year, due to the unexpectedly rich findings. The evidence recovered so far indicates that the Northeast Annex saw an intense use starting from the primary construction of the fortress. Its architectural installations underwent a series of alterations which changed the size and the layout of Rooms 85A to C apparently still during the Middle Kingdom. Evidence of later periods is limited and probably all of Late Medieval date. Work in the area shall continue in the next season, completely exposing the mudbrick floor (Room 87), the structure south of Rooms $85 \mathrm{~A}$ to $\mathrm{C}$ and the area east of it where traces of mudbrick walls which had not been recorded by Wheeler were detected this year.

\subsection{Excavation Area 2: North Wing Wall}

A small $2 \times 2 \mathrm{~m}$ trench was opened to clarify the point where North Wing Wall, i.e. the main fortificatory installation north of the fortress, abuts the main curtain wall, i.e. North Wall (fig. 2). After a considerable amount of dump from Wheeler's excavations which covered the outer parts of these walls had been removed, it showed that the niche formed at this juncture still preserved much of its original finish in terms of plaster and colouring. The latter consisted of a white wash which was overlain by yellow in the lower part (fig. 12). The yellow colour had been applied in curved strokes, giving the entire scheme a lively, garland like appearance.

In front of the niche, parts of a working horizon were preserved. Patches of a hardened mud floor were still recognizable as well as depositions of ground white and yellow materials which seemed to be associated with it, although a direct stratigraphic correlation could not be established. Among the finds from this area was a sherd which preserves copious amounts of yellow and white paint (fig. 13). Its exact function in the process of preparing and/or applying the paint has not yet been clarified, but its ground edges identify it as a tool sherd. The entire assemblage constituted the workplace where the colours for painting the outer face of North Wing Wall (and possibly the outer face of North Wall West as well) had been prepared.

Remains of wall paint have been observed in several fortresses. Rooms 21 and 22 in Shalfak each displayed two superimposed layers of plaster painted in black, red, yellow and white. ${ }^{68}$ House 2 in Quban had remains of a base panel painted in the same colours. ${ }^{69}$ At Buhen, the Middle and New Kingdom outer facades of the enclosure wall were "faced with white-painted plaster". ${ }^{70}$ The inner side of the northern section of the curtain wall at Semna "had been plastered white below and yellow above" ${ }^{71}$ While it was known that the fortress walls had been painted, no data about the nature of that paint were available so far. Carola Vogel ${ }^{72}$ had assumed a complete cover with white gypsum on the grounds of linguistic - referring to jnb.w HD - and pictorial evidence. Unexpectedly, the analysis of the white material on the Shalfak sherd proved it to be talc. ${ }^{73}$ No use of powdered talc - as material for painting or any other purpose - has been demonstrated so far, despite talc is the main component of steatite, which was widely employed for stone objects throughout the Pharaonic period. ${ }^{74}$ An observation which is relevant with regard to this finding is the repeated occurrence of small chunks, flakes and chips of a white to light-green stone on the surface and in the deposits of the site. This stone was worked by the occupants of the fortress, as several small finds illustrate (see

\footnotetext{
${ }^{68}$ Dunham, Uronarti, Shalfak, Mirgissa, 118, pl. LIV.A-C.

${ }^{69}$ Emery, and Kirwan, Excavations and Survey, 38, fig. 16.

${ }^{70}$ W. B. Emery, H. S. Smith, and A. Millard, The Fortress of Buhen: The Archaeological Report (MEES 49; London, 1979), 5, 13.

71 Janssen and Dunham, Semna, Kumma, 6.

${ }^{72}$ Festungen, 120.

${ }^{73}$ The analysis was undertaken by Kate Fulcher of the Institute of Archaeology, University College London.

${ }^{74}$ For other materials used to produce white paint see L. Lee, and S. Quirke, 'Painting Materials', in P. T. Nicholson and I. Shaw (eds), Ancient Egyptian Materials and Technology (Cambridge, 2000), 114-15.
} 
below 5.2.). The analysis of an unworked piece collected at the site surface identified it as a metamorphic carbonate rock. Talc in turn is a mineral composed of hydrated magnesium silicate which is formed in metamorphic belts that contain carbonate rocks.

Veins of the whitish-green stone were recorded in the outcrops west of Shalfak during a short reconnaissance this year. While this strand requires further investigations to exactly match and geologically characterise these deposits, the pieces of raw material found at the site as well as the finished objects and the pigments from the workplace, the sherd and the walls, it seems likely that the occupants of the fortress exploited a local source for this group of raw materials, using them for manufacturing a range of objects as well as producing pigments to paint the fortress walls.

The evidence from Excavation Area 2 sheds light on two major questions pursued in the Shalfak project, namely which resources were mobilised to build and maintain the fortress and how their exploitation was organised. From the available data we can conclude that the builders used local raw materials to paint the fortress. Thus, they must have been familiar with local sources and chose to exploit them rather than importing other types of pigment. The - contemporary or later - occupants continued to frequent the same or similar deposits to obtain raw material for producing a range of objects for daily use.

Beyond the evidence from Shalfak, the use of light-coloured metamorphic carbonate rock shall be illustrated by just one prominent example: a small seated statue of Amenemhat III, identified as ophicalcite, which reportedly originates from the Fayum. ${ }^{75}$ The sculpture illustrates the appreciation of the Middle Kingdom Egyptians for this material and its use in a wide range of material production.

\subsection{Excavation Area 3: Block I, Rooms 7 to 9}

To supplement the investigation of Excavation Area 1 by probing potential areas for a temple or chapel, another excavation was opened to re-investigate Rooms 7 to 9 in Block I (figs 2, 14). They form a three-roomed structure, comprising an almost square entrance room (9) and two elongated rooms $(7,8)$ in the rear. Not least since this assemblage almost faces the main gate of the fortress, Wheeler ${ }^{76}$ suggested that it may have functioned as a temple. In Dunham's 1967 publication it is described as follows:

"The three Rooms 7 to 9 consist of a hall with one sandstone column-base and with two interior rooms leading out of it. The hall has a main door into South Wall Street nearly opposite South Gate, and had in its northeast corner an inscribed circular sandstone basin with a dedicatory inscription round the rim [...]. The two inner rooms have had small magazines added to them. Rooms 7 to 9 appear to have been a temple or chapel. [...] The main doorway of Room $9^{[77]}$ has wooden cornerposts both inside and out [...]. The doorway of Room $9^{[78]}$ has a timber sill and wooden doorposts of square section. The doorway of Room 8 has a sandstone sill and part of one stone jamb."79

All wooden corner- and doorposts as well as the stone jamb mentioned in the description have been lost in the meantime. A photograph of the rooms after the 1931 excavation shows fragments of what

\footnotetext{
${ }^{75}$ The piece of which only the upper part is preserved is kept in the Staatliche Museum Ägyptischer Kunst in Munich, ÄS 6762, today.

${ }^{76}$ Wheeler, BMFA 29, 69 and Wheeler, SNR 15, 252.

${ }^{77}$ See also Dunham, Uronarti, Shalfak, Mirgissa, pl. XLVII.A which shows the two square doorposts on the outer face of the door.

${ }^{78}$ This should probably read "Room 7", as this room has a timber sill. The sill was overbuilt by the south wall of Room 7 which was a later addition (fig. XXX and see the discussion of Room 7 in the next but two paragraphs). The presence of the sill suggests that the entrance to Room 7 had originally been further east than the present access.

${ }^{79}$ Dunham, Uronarti, Shalfak, Mirgissa, 116.
} 
seems to be a stone door sill in the entrance to Room 9 which is also gone. ${ }^{80}$ Today, Room 9 still preserves part of a mudbrick floor (fig. 14). In several places where the mudbricks have been lost an underlying levelling layer of mud can be seen. Other places show a mud floor on top of the bricks. Both layers are composed of areas of differing quality. The fragmentary column base has been dislocated. The mudbrick floor also preserves the depression into which the sandstone basin mentioned by Dunham was set. A detailed study of this object is currently prepared by W. V. Davies and will hopefully add new aspects to our understanding of the room. ${ }^{81}$ On top, the remains of several wooden posts were found: Two in the northwest corner of the room, one in the southwest, one at the entrance, and five in the centre of the room.

Room 8 had been cleared down to the bedrock almost completely, and beyond that several shallow pits had been pecked into the rock (fig. 14). While it is unclear whether this tabula rasa excavation is to be attributed to Wheeler, few archaeologically relevant deposits remain. Floors are widely lost, only few places preserve patches of mud on the underlying bedrock. The remains of installations which may originally have furnished this room were too scant to allow a comprehensive reconstruction and a functional interpretation. They include what seemed to be wall collapse and a platform built of mudbricks, both in the rear part of the room (fig. 15). ${ }^{82}$ The entrance to the room is still equipped with a fragmentary sandstone threshold, complete with the hole of a door hinge, on top of the mudbrick floor in situ (fig. 14).

Room 7 has a mud floor which has been destroyed in several places (fig. 14). It is composed of several layers which often cannot be clearly differentiated and together form a package of $3-5 \mathrm{~cm}$ strength on top of the bedrock. Mudbricks were only present in the entrance to the room where they had been placed as a threshold. Remains of wall plaster in the northeastern corner of the room show traces of burning. These traces and the presence of charcoal in the floor suggest that the area originally held a fireplace. The charcoal was identified as Acacia sp. Room 7 still displayed two mudbrick installations (fig. 14). Kemp ${ }^{83}$ identified the structure in the centre of the west wall as a "quern emplacement", citing a parallel complete with quern stone from Deir el-Medina. ${ }^{84}$ However, the installation in Room 7 does not have the raised part for the quern and a collecting basin at floor level, but simply consists of two compartments at floor level, outlined by a row of bricks laid in stretchers (fig. 16). In the two interior spaces of the compartment, ash and charcoal were found. The charcoal was identified as Acacia sp. and Capparis decidua. Another observation concerns the wall plaster which continues into the southeastern corner of Room 7 (fig. 14), indicating that the south wall was added only later, after the original plastering of the room. It replaced an earlier entrance whose wooden sill is still visible under the southern face of the later wall (figs 14, 17). Whether the mudbrick installation in the southastern corner of Room 7 was built together with the wall could not be ascertained.

Kemp suggested that the three-room suite belonged to the granary which forms the west part of Block I (fig. 2). He assumed that the access to the six storerooms (1-6) which displayed "no sign of any doorway through an outer wall [...] must have been from a wooden ladder placed in the adjacent room containing the sandstone column base (no. 9). This base could have supported either an overall roof, or a veranda shading the rear part only" ${ }^{85} \mathrm{~A}$ similar alignment of the administrative tract - or

\footnotetext{
${ }^{80}$ Dunham, Uronarti, Shalfak, Mirgissa, pl. XLVII.A.

${ }^{81}$ For the object see Dunham, Uronarti, Shalfak, Mirgissa, 129, pl. LX. The whereabouts of this basin are unknown.

${ }^{82}$ Wheeler interpreted the presumable mudbrick collapse as a flimsy wall separating off the back of Room 8 ; see Reisner, Kush 8, plan 2 and Dunham, Uronarti, Shalfak, Mirgissa, map X.

${ }^{83}$ ZÄS 113, 124, fig. 3. Ditto Vogel, Festungen, 135.

${ }^{84}$ B. Bruyère, Rapport sur les fouilles de Deir el Médineh (années 1948 à 1951) (FIFAO 26; Cairo 1953), 96-9, fig. 28. For a model of a double quern emplacement see also H. E. Winlock, Models of Daily Life in Ancient Egypt: From the Tomb of Meket-Re'-' at Thebes (PMMA 18; Cambridge, Mass., 1955), 88, pls 22-23, 64-65.

${ }^{85}$ Kemp, ZÄS 113, 124.
} 
perhaps better: the activity area - and the actual granary appears in Middle Kingdom models, e.g. the model from the tomb of Meketre, though this area is confined to a single room in this case. ${ }^{86}$

In sum, the excavation produced no indication that Rooms 7 to 9 had served as a temple or chapel. Instead, the mudbrick installations and the traces of fire in Room 7 suggest a use in a domestic or workshop context, probably related to the adjacent granary.

\section{Finds}

An important observation of the current season is that the most informative finds did not derive from the excavations, but from the site surface and the dumps of the 1931 excavation. This may be a pattern which Shalfak shares with other sites of a similar history of research. Digging up Wheeler's dumps may eventually prove more productive in terms of finds than re-excavations at the site proper. The potential of these dislocated objects for chronological research has recently been demonstrated at Uronarti. ${ }^{87}$ An ongoing challenge is to re-contextualise the material in order to widen its analytical potential also beyond chronology.

\subsection{Pottery}

The situation just described is particularily pronounced for the pottery. In Shalfak, diagnostic sherds litter the site surface, while the excavations produced almost no such material. This requires a rethinking of the pottery analysis, which will have to depart from conventional methodologies and interpretive approaches. For the time being, two observations can be reported. As in other Middle Kingdom fortresses, Nubian ceramics are also present at Shalfak (fig. 18). ${ }^{88}$ They occur in small quantities in all larger surface collections from the site. They may, however, be overrepresented in these assemblages as they stick out from the reminder of the material due to their visual deviation and are thus more likely to be picked up. Another distinct group is the Gilded Ware, or more prosaically micaceous slipped pottery, which is present in a variety of shapes at Shafalk (fig. 19). ${ }^{89}$

\subsection{Small finds}

The finds from Excavation Area 1 comprise animal bones and shells, some lithic implements, slag, a small faience rod and a few beads. A small bronze (?) hook was found near the basin in Room 87. From the surface of the excavation area, the fragment of an alabaster lid (fig. 20), a pottery knob (fig. 20) and a mud sealing (fig. 21) were collected. As only a limited number of sealings have been found at Shalfak so far, ${ }^{90}$ the latter is of particular interest and receives a detailed discussion in Appendix 1.

Excavation Area 2 produced animal bones, a stone bladelet, the tool sherd (fig. 13) and a small weight (fig. 20). The latter was found on the surface and may have come to that location with Wheeler's debris which covers part of Excavation Area 2. The weight is of the light green stone that

\footnotetext{
${ }^{86}$ Winlock, Models, 87, pls. 20, 62. For a recent discussion see N. Allon, Model of a granary with scribes, in A. Oppenheim et al. (eds), Ancient Egypt Transformed: The Middle Kingdom (New York 2015), 158-9 no. 93.

${ }^{87}$ See Knoblauch and Bestock, MDAIK 69 (2013), 116-19.

${ }^{88} \mathrm{Cf}$. e.g. Bestock and Knoblauch, Journal of Ancient Egyptian Interconnections 6, 35, fig. 2 and Smith, Askut, figs 3.16, 4.10 .

${ }^{89}$ See C. Knoblauch, 'Not all that Glitters: A Case Study of Regional Aspects of Egyptian Middle Kingdom Pottery Production in Lower Nubia and the Second Cataract', CCE 9 (2011), 167-83. For the occurence of this ware at Uronarti see Knoblauch and Bestock, MDAIK 69 (2013), 119.

${ }^{90}$ A. L. Foster, 'Sealings from Shalfak, a Middle Kingdom Fortress in Nubia', in M. Perna (ed.), Administrative Documents in the Aegean and their Near Eastern Counterparts: Proceedings of the International Colloquium, Naples, February 29-March 2, 1996 (Turin, 2000), 171-83.
} 
was discussed in connection with the talc-based paint above (see 4.2.). ${ }^{91}$ Other finds from this material recoverd in the current season include a small grinder and what may have been a small lithic borer, both picked up from the site surface.

From Excavation Area 3, i.e. Rooms 7 to 9, animal bones, beads, small faience rods, a fragmented Bes amulet as well as small pieces of faience (possibly from a bowl) and what may be lapis lazuli were recovered despite the previous thorough clearance of the complex by Wheeler.

General surface finds from the site include beads, lithics, a small faience rod, the rim fragment of a faience bowl, further faience fragments, a pottery spool (fig. 20) and a seal (fig. 20). An unexpected discovery were eight pan-grave spacers (fig. 22) which came to light when a corner of Room 56 was cleared from windblown sand during the mapping survey. As these spacers are closely connected to Pan-Grave ethnic identities, they may be another indication for the presence of Nubians at Shalfak.

\section{Regional survey}

The survey aims to retrace and map previously reported sites and to identify further sites in the hinterland of the fortress. Contrary to Uronarti, not much of Shalfak's immediate surroundings stayed above the water. Known sites in this area include two cemeteries (East and West Cemetery) which were explored by Wheeler and have been associated with the occupation of the fortress. ${ }^{92}$ They were under water during the current field season and are probably permanently submerged. Furthermore, two rock inscriptions were recorded in the 1960s. ${ }^{93}$ Apart from these, only few sites were documented in the vicinity of the fortress during survey activities in the 1960s. ${ }^{94}$ The nearest sites of Pharaonic date are Uronarti fortress about $5 \mathrm{~km}$ upstream and a gold mining area with associated workshops in the plain of Saras about $5 \mathrm{~km}$ downstream. The mine proper (11-Q-60), which is the highest and most remote of this series of sites, may just be above the water, and a reconnaissance of the area is planned for future seasons. The nearest fortress downriver was Askut, about $10 \mathrm{~km}$ from Shalfak, which is now submerged.

The area east of Shalfak, i.e. the former east bank of the Nile, is comparatively low-lying and a wide stretch of it has been drowned by Lake Nubia. Therefore, survey activities concentrated on the hinterland west of the fortress. A small reconnaissance, covering a radius of about $1 \mathrm{~km}$, produced ample evidence of further sites. The majority are isolated graves built into the rocky outcrops in the way of cleft, alcove or dome graves (fig. 23). ${ }^{95}$ They occupy almost every hilltop, making the area an extended burial landscape. All graves we encountered were plundered. Due to the absence of diagnostic finds, they are impossible to date. Another interesting site is an agglomeration of stone settings which indicate a settlement (SAM002; fig. 24). The site is located on a sandy hillside about

\footnotetext{
${ }^{91}$ For comparable objects see e.g. a group of weights as well as a number of individual specimens of different materials from Uronarti (Dunham, Uronarti, Shalfak, Mirgissa, 35-6, pl. XXXV.A, B) as well as other specimens from Semna (Janssen and Dunham, Semna, Kumma, 65, fig. 29).

${ }^{92}$ Dunham, Uronarti, Shalfak, Mirgissa, 121-3, pls LV-LIX, maps XIII-XV.

${ }^{93}$ F. Hintze, Preliminary note on the Epigraphic Expedition to Sudanese Nubia, 1963, Kush 13 (1965), 14-15; F. Hintze and W. Reineke, Felsinschriften aus dem sudanesischen Nubien. Publikation der Nubien-Expedition 1961-1963 (Berlin, 1989), vol. I, 90-1, II, 122 nos 365-6. See also W. V. Davies, 'Tombos and the Viceroy Inebny/Amenemnekhu', British Museum Studies in Ancient Egypt and Sudan 10 (2008), 41-6.

${ }^{94}$ A. J. Mills and H.-Å. Nordström, The archaeological survey from Gemai to Dal. Preliminary report on the season 1964-65, Kush 14 (1966), 1-15; A. J. Mills, The archaeological survey from Gemai to Dal. Report on the 1965-1966 season, Kush 15 (1967-68), 200-10; D. N. Edwards and A. J. Mills, 'Pharaonic' sites in the Batn elHajar - the 'Archaeological Survey of Sudanese Nubia' revisited, Sudan \& Nubia 17 (2013), 8-17.

${ }^{95}$ For these types of graves see the evidence from the Fourth Cataract, systematised e.g. in H. Paner, and Z. Borcowski, 'Gdańsk Archaeological Museum Expedition. A Summary of Eight Seasons' Work at the Fourth Cataract', in H. Paner, and S. Jakobielski (eds), Proceedings of the "Archaeology opf the Fourth Nile Cataract". Gdańsk - Gniew, 23-25 July 2004 (Gdańsk Archaeological Museum African Reports 4, 2005), 112-13.
} 
$630 \mathrm{~m}$ from the fortress, in plain view from South Gate. It remains to be established whether it is contemporary to the fortress.

\title{
7. Outlook
}

Shalfak is the smallest of the Nubian Middle Kingdom fortresses. ${ }^{96}$ There is a wide agreement that it was built under Senusret III (1872-1853 BC) as part of the second phase of the construction of the Nubian fortresses. ${ }^{97}$ So far, the use-life of Shalfak has only been determined in the most general terms as spanning the period from its primary occupation into the New Kingdom. ${ }^{98}$ Trigger $^{99}$ actually assumed Shalfak "to have been totally abandoned" after the re-occupation of Nubia in the early New Kingdom. However, two rock inscriptions testify to the presence of Egyptian functionaries at Shalfak in Year 18 of Hatshepsut ${ }^{100}$, while an endowment text preserved on the walls of the temple in Semna relates to cult activities in Shalfak in the reign of Thutmose III. ${ }^{101}$

The data collected in the first field season of the Shalfak Archaeological Mission indicate an intense occupation, including building alterations, immediately following the construction of the fortress. The three excavation presented in this paper preserve very little in terms of stratigraphic evidence. While in part this is doubtlessly due to Wheeler's 1931 clearances, the overall impression is that much of the extant architectural remains at Shalfak are from the Middle Kingdom and that this reflects the actual building history and use-life of the monument.

Investigations conducted this year put to rest the tentative identification of Rooms 7 to 9 and the Northeast Annex as locations of chapels. Rather, the evidence available suggests that Rooms 7 to 9 were the activity area of the attached granary. The Northeast Annex can be defined as a workshop and/or storage space. With the investigation progressing, these results may help to better understand the administration of storage and rationing which were key element of the function and the organisation of the fortresses. The micaceous pottery and the letter sealing add information on how the fortresses were linked to each other in terms of cultural influences and actual communication. The presence of Nubian pottery and jewellery allows a glimpse at the organisation of everyday life in the fortress, which apparently encompassed Nubian occupants, too. In all, the first season at Shalfak yielded rich evidence and amply illustrated the potential of the site for extending our understanding of the Nubian Middle Kingdom fortresses as military and administrative installations as well as arenas of every-day life in the Middle Kingdom and beyond.

\section{Appendix: The newly discovered seal impression}

\author{
by Wolfram Grajetzki
}

\footnotetext{
${ }^{96}$ An exception is Semna South which is, however, usually not considered as a fortress proper, but a fortified camp (Vogel, Festungen, 264-6 with further references).

97 Vogel, Festungen, 73-7 with further references.

98 Vogel, Festungen, 249; E. F. Morris, The Architecture of Imperialism: Military Bases and the Evolution of Foreign Policy in Egypt's New Kingdom (PdÄ 22; Leiden, and Boston, 2005) 100, quoting A. J. Arkell Arkell, A History of the Sudan from the Earliest Times to 1821 (London, 1955), 102 and B. G. Trigger, History and Settlement in Lower Nubia (Yale University Publications in Anthropology 69; New Haven, 1965), 109; B. G. Trigger, Nubia under the Pharaohs (London, 1976), 123.

${ }^{99}$ Settlement, 109.

${ }^{100}$ F. Hintze, Preliminary note on the Epigraphic Expedition to Sudanese Nubia, 1963, Kush 13 (1965), 14-15; F. Hintze and W. Reineke, Felsinschriften aus dem sudanesischen Nubien. Publikation der Nubien-Expedition 1961-1963. 2 vols (Berlin, 1989), I, 90-91, II, 122 nos 365-6; W. V. Davies, British Museum Studies in Ancient Egypt and Sudan 10, 41-6.

101 Urk. IV, 196. The text mentions the cult of a queen Meretseger at Shalfak. The name of this queen also appears on the sandstone basin found in Room 9 of Block I by Wheeler (Dunham, Uronarti, Shalfak, Mirgissa, pl. LX); see above p. XXX.
} 
The newly found seal impression (fig. 21) comes from a scarab of the category naming a government department and is identical to four clay seal impressions found at Uronarti. ${ }^{102}$ The text on it reads $x A$ $\mathrm{n}$ zAb tAity nwt rsi - 'bureau of the dignitary, the one belonging to the curtain, southern city'. At the top and bottom there is a spiral pattern. From the traces on the underside it seems clear that this clay seal impression was once attached to a letter.

The title zAb ('dignitary') is common in the late Middle Kingdom, but the functions of the title holders are not always clear. ${ }^{103}$ The title also appears in title strings of viziers. The title tAity ('the one belonging to the curtain') is typical for viziers and only used in their title strings. It is only very rarely attested in the late Middle Kingdom. ${ }^{104}$ The 'southern city' refers to Thebes. ${ }^{105}$

The seal used for stamping the (lost) letter therefore belongs to the Theban vizier's office. The titles $\mathrm{zAb}$ and tAity are those of a vizier, but they are not his main titles. Instead, viziers in the late Middle Kingdom most often bear the title string imy-r nwt TAti ('overseer of the city, vizier') or less often simply the title 'vizier'. ${ }^{106}$ On other sealings, the same (?) institution is clearly called 'vizier's bureau' (HA ( $n$ ) TAty) $)^{107}$ or 'bureau' of the vizier and one belonging to the curtain' (HA ( $n$ ) TAti tAity) ${ }^{108}$. It remains unclear why in the case of the newly found seal and those from Uronarti the title 'vizier' is missing. An alternative designation 'vizier's bureau for the head of the south' (tp rs) occurs on other seal impressions from Uronarti. ${ }^{109} \mathrm{~S}$. T. Smith wondered whether the Theban vizier's office mainly sent letters to private people, while the 'head of the South' was mainly corresponding with officials, as the distribution of the seal impressions found at Uronarti seems to indicate. ${ }^{110}$

The inscription on the Shalfalk seal impression is especially worn in the middle where the ' $p r$ ' and the ' $n$ ' sign in the writing of HA $n$ ('bureau of') can be reconstructed. The same damage seems to occur on the seal impressions found at Uronarti, according to the drawing in the excavation report. ${ }^{111}$ This provides the impression that the scarab used for sealing was already worn and that we are actually facing one and the same seal that was used for sealing letters that were sent both to Uronarti and to Shalfak.

\footnotetext{
102 G. T. Martin, Egyptian Administrative and Private-Name Seals (Oxford, 1971), pl. 47 [9]: no. 1845; Dunham, Uronarti, Shalfak, Mirgissa, 47 [28-12-230], 52 [29-1-17], 53 [29-1-125], 58 [30-2-14], 65 [8; drawing].

103 S. Quirke, 'Four Titles. What is the Difference?' in D. Silverman, W. K. Simpson, and J. Wegner (eds), Archaism and Innovation. Studies in the Culture of Middle Kingdom Egypt (New Haven, and Philadelphia, 2009), 305-17.

${ }^{104}$ W. Grajetzki, Die höchsten Beamten der ägytischen Zentralverwaltung (Berlin, 2000), 34-5.

105 F. Gomaa, Die Besiedlung Ägyptens während des Mittleren Reiches, 1. Oberägypten und das Fayyum (Wiesbaden, 1986), 100-1.

106 W. Grajetzki, Die höchsten Beamten, 34-5.

107 Martin, Seals, nos 1846, 1848, 1848a, 1849.

108 Martin, Seals, no. 1847a.

${ }^{109}$ Martin, Seals, no. 1849.

${ }^{110}$ Smith, in Palaima (ed.), Aegean Seals, Sealings and Administration, 210.

111 Dunham, Uronarti, Shalfak, Mirgissa, 65 [8; drawing]. In Martin, Seals, no. 1845, pl. 47 [9] the text is presented as undamaged.
} 
Fig. 1 Interior of Shalfak fortress, looking north, with Block II in the foreground (Claudia Näser)

Fig. 2 Plan of Shalfak fortress (data generation: Peter Becker, Kay Kossatz; graphic implementation: Kay Kossatz)

Fig. 3 Digital elevation model of the curtain walls and Blocks I and II, indicating wall heights (data generation: Peter Becker, Kay Kossatz; graphic implementation: Kay Kossatz)

Fig. 4 A wooden beam and a layer of matting at the inner face of East Wall South (Claudia Näser)

Fig. 5 The remains of transversal logs at the inner face of South Wall, east of South Gate (Claudia Näser)

Fig. 6 Mat with binding and mortar on top, East Wall North (Kay Kossatz)

Fig. 7 View of Excavation Area 1 from southwest (Claudia Näser)

Fig. 8 Plane 1 of Excavation Area 1 (drawing: Claudia Näser; graphic implementation: Kateryna Kortschagina)

Fig. 9 Basin in Room 87 before excavation (Claudia Näser)

Fig. 10 Section of basin in Room 87 (drawing: Claudia Näser, Osman Khaleel Elawad Karrar; graphic implementation: Kay Kossatz)

Fig. 11 Basin in Room 87 after excavation (Claudia Näser)

Fig. 12 The southernmost niche of North Wing Wall (Claudia Näser)

Fig. 13 Sherd with yellow and white paint from the workplace in front of the southernmost niche of North Wing Wall (Kay Kossatz)

Fig. 14 Plane 2 of Rooms 7 to 9 (drawing: Peter Becker, Kay Kossatz, Osman Khaleel Elawad Karrar; graphic implementation: Kay Kossatz)

Fig. 15 Features in Room 8 (Claudia Näser)

Fig. 16 Installation in front of the west wall of Room 7 (Kay Kossatz)

Fig. 17 Sill under the south wall of Room 7, seen from Room 9 (Kay Kossatz)

Fig. 18 Selection of Nubian pottery (Kay Kossatz)

Fig. 19 Selection of micaceous ware pottery (Kay Kossatz)

Fig. 20 Selection of small finds (drawing: Peter Becker, Claudia Näser; graphic implementation: Kay Kossatz)

Fig. 21 Mud sealing (Kay Kossatz)

Fig. 22 Pan-Grave spacers from Room 56 (Kay Kossatz)

Fig. 23 Remains of a dome grave in the hinterland west of Shalfak (Claudia Näser)

Fig. 24 Settlement site SAM002 (Claudia Näser) 


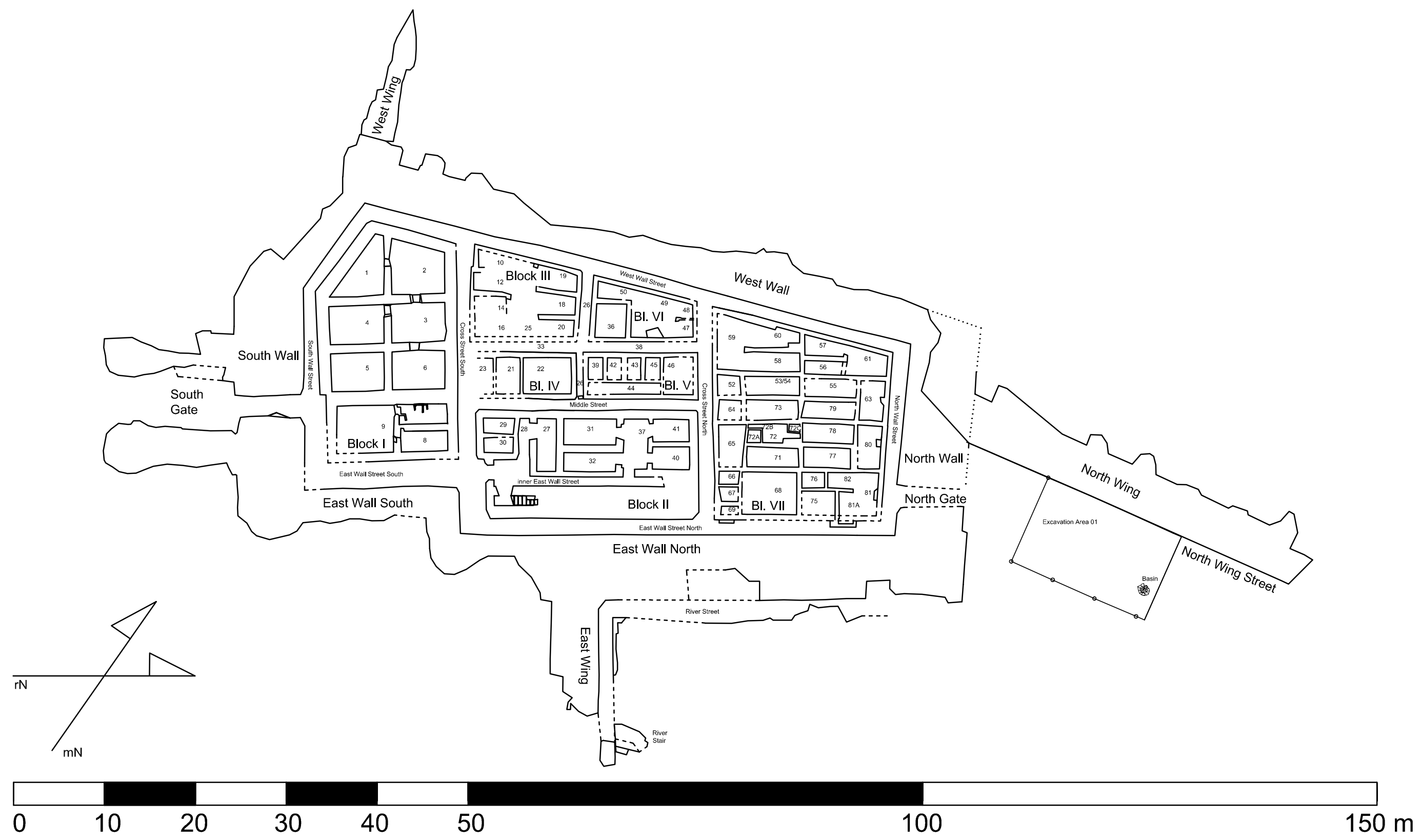




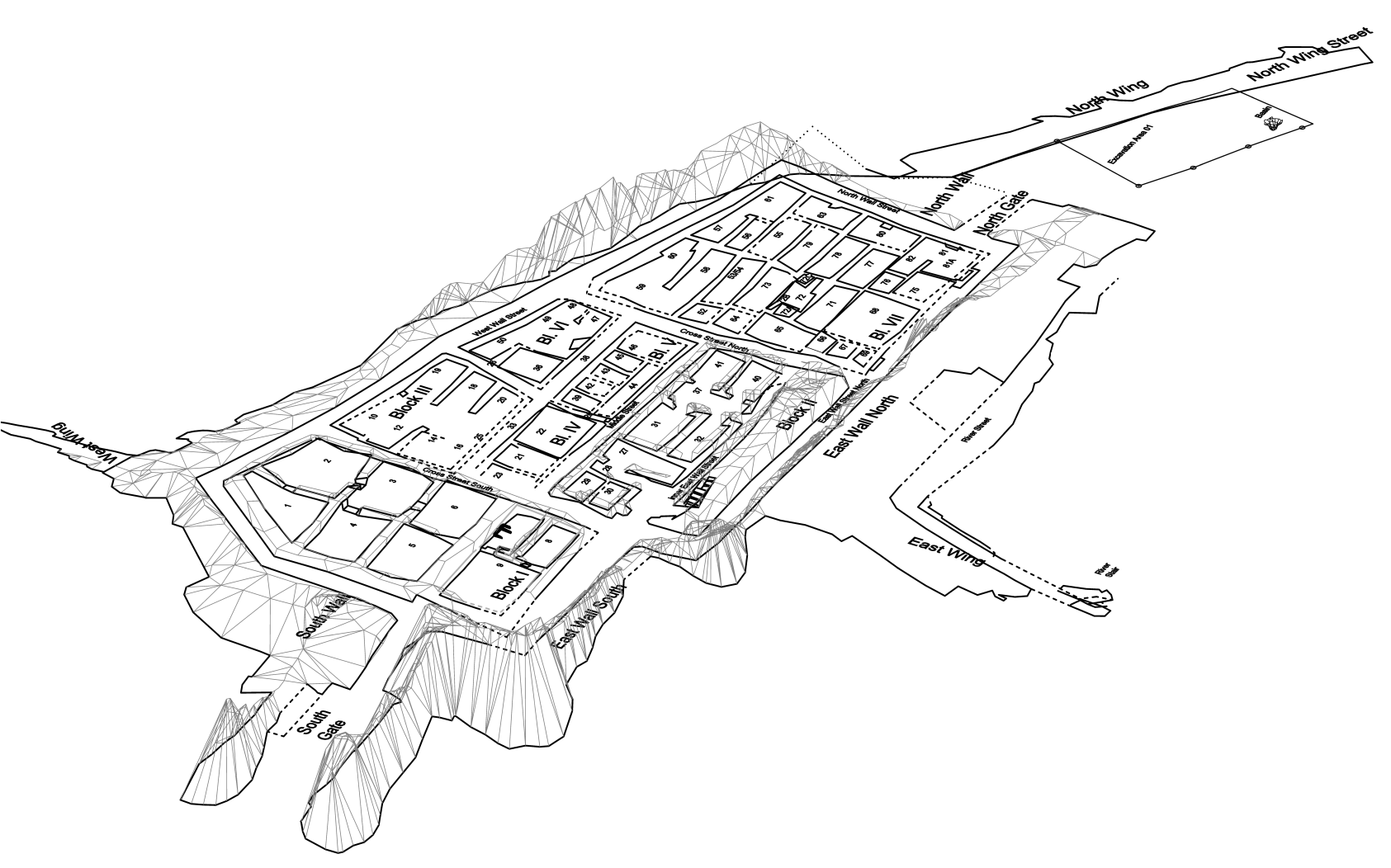




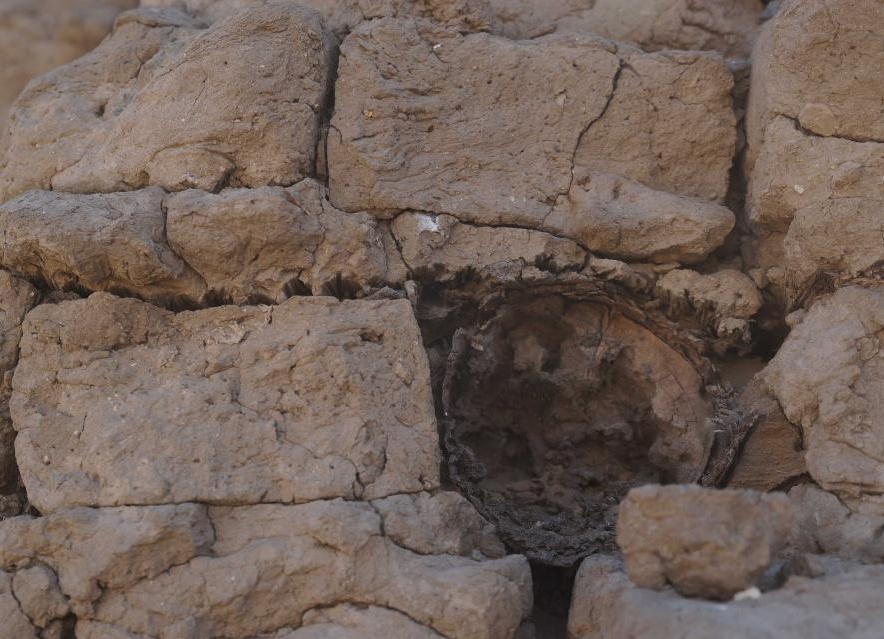




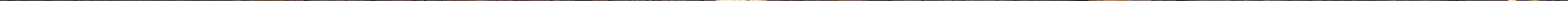




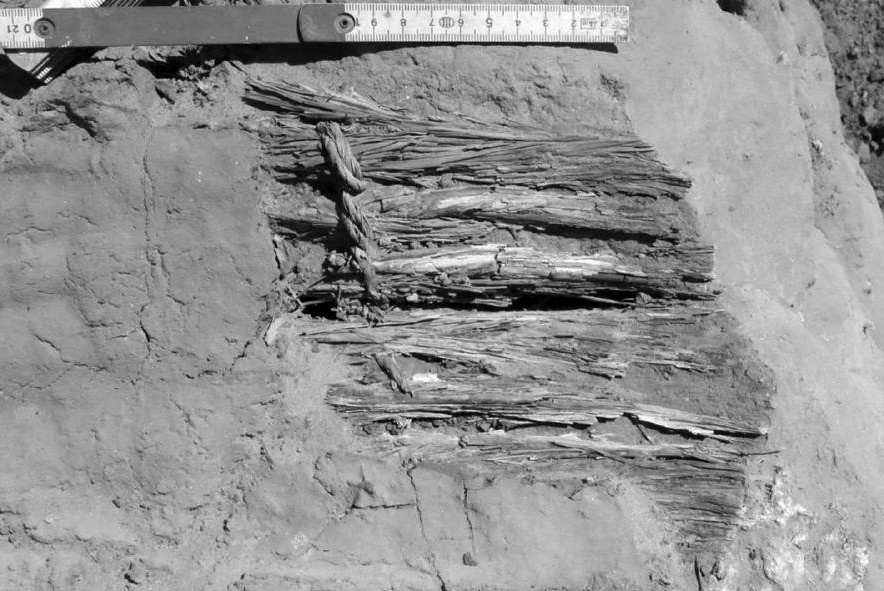




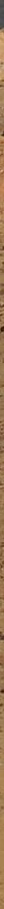









\begin{tabular}{|c|c|c|c|c|c|}
\hline & mudbrick wall, phase 1 & mud mortar (wall) & fireplace & $1--1$ & section (basin) \\
\hline & mudbrick wall, phase 2 & plaster (floor) & stone & $\mathrm{mN}$ & magnetic North \\
\hline & mudbrick wall, phase 3 & plaster (wall) & granite & $\mathrm{rN}$ & river North \\
\hline & mudbrick floor & organic material & pottery & & \\
\hline 00 & rubble fill & mud mortar (basin) & disturbance & & \\
\hline
\end{tabular}





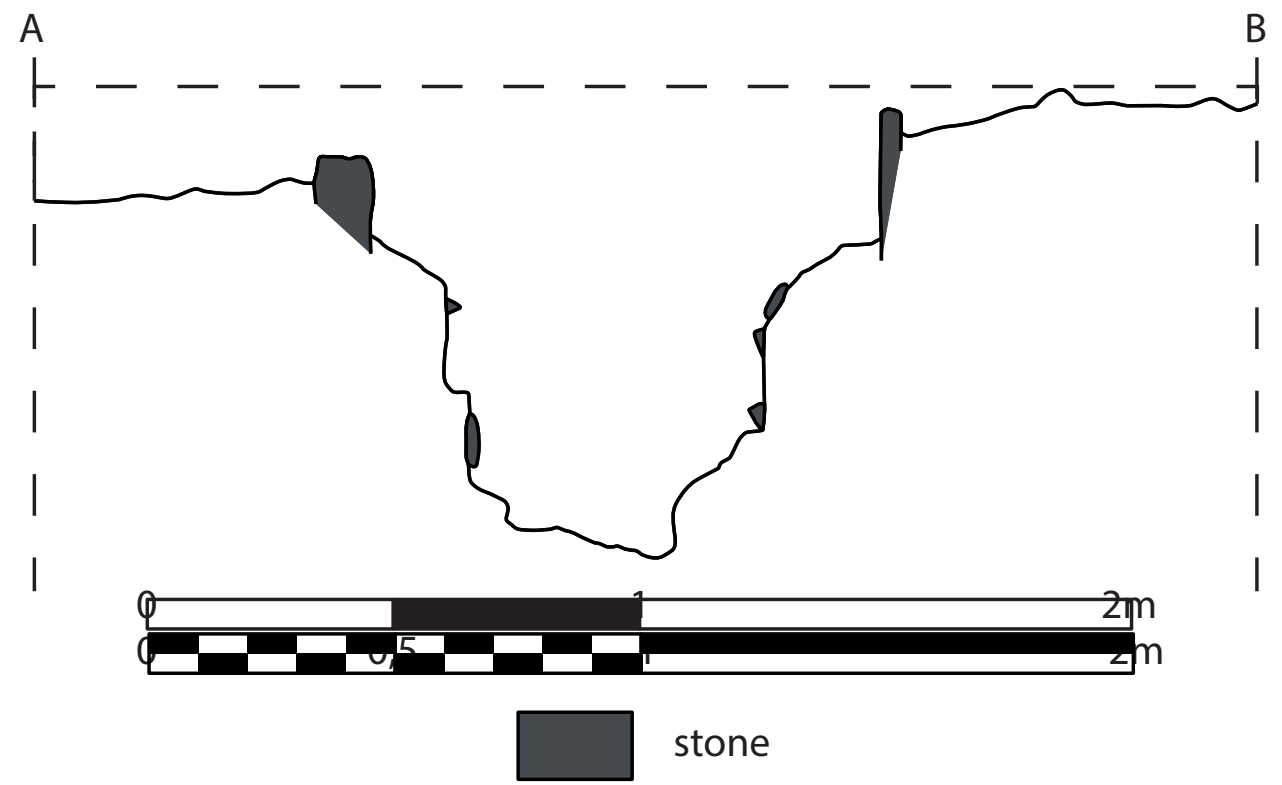




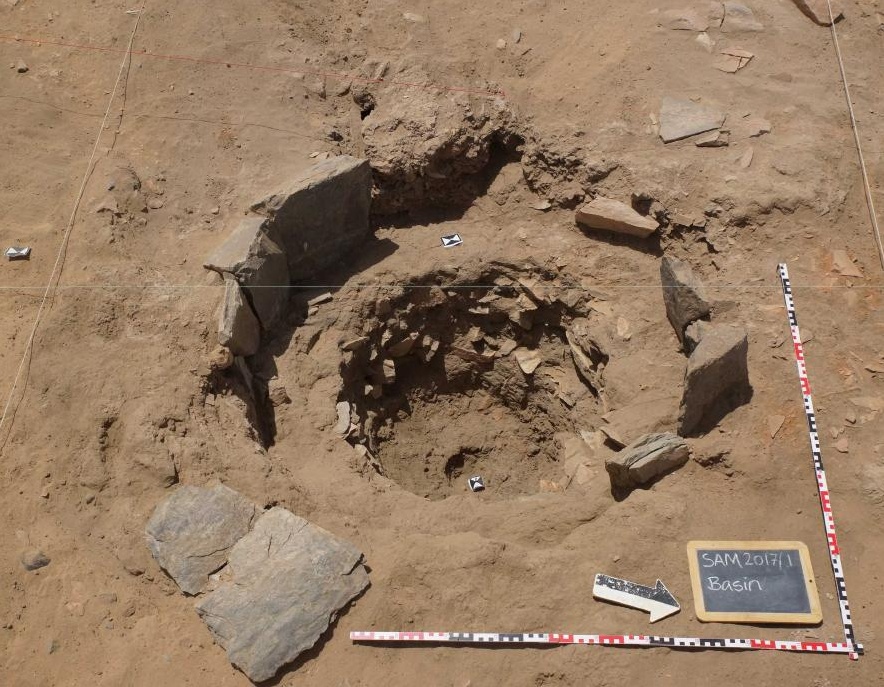




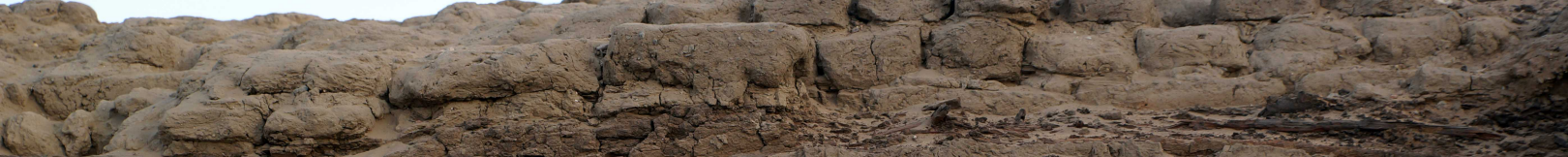

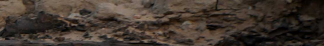
$+\frac{1}{2+1}$

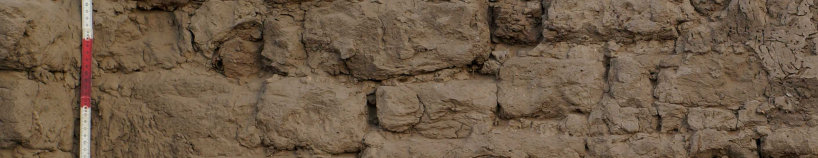

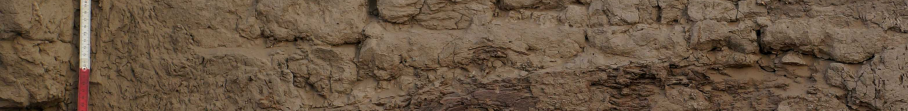
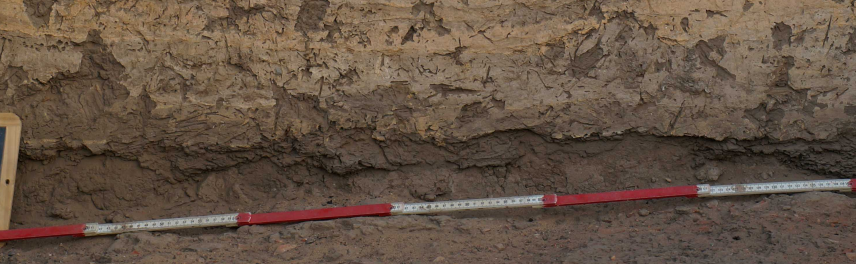

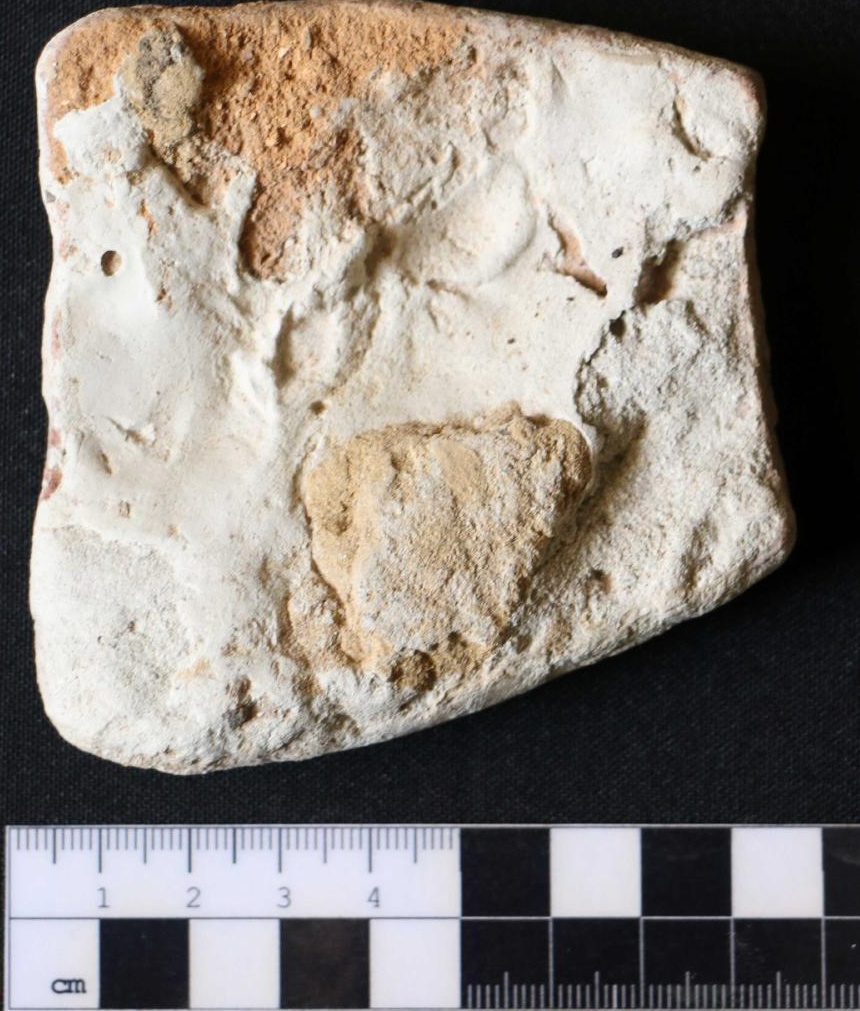





$\mathrm{mN}$ magnetic North

rN river North mudbrick floor $\quad \square$ mud mortar

mudbrick wall (schematic) — plaster (wall)

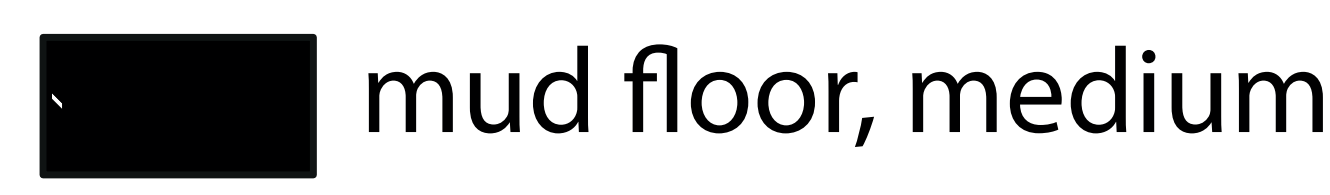

$\therefore \therefore$ mud levelling layer, coarse

$\because \therefore$ mud levelling layer, very coarse mudbrick installation

traces of fire wood

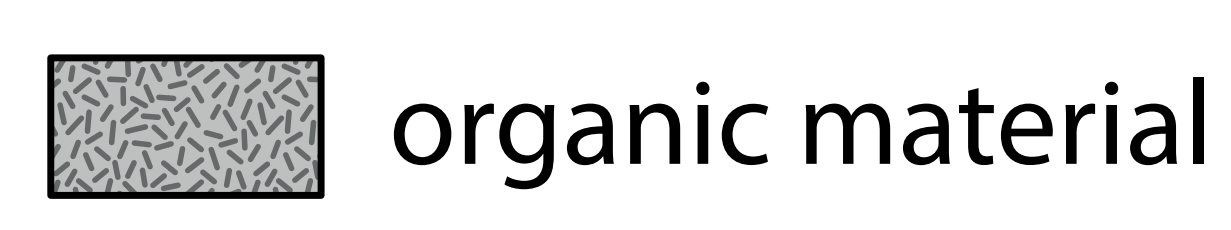

pottery $\square \square$ disturbance

shell

charcoal

ash 


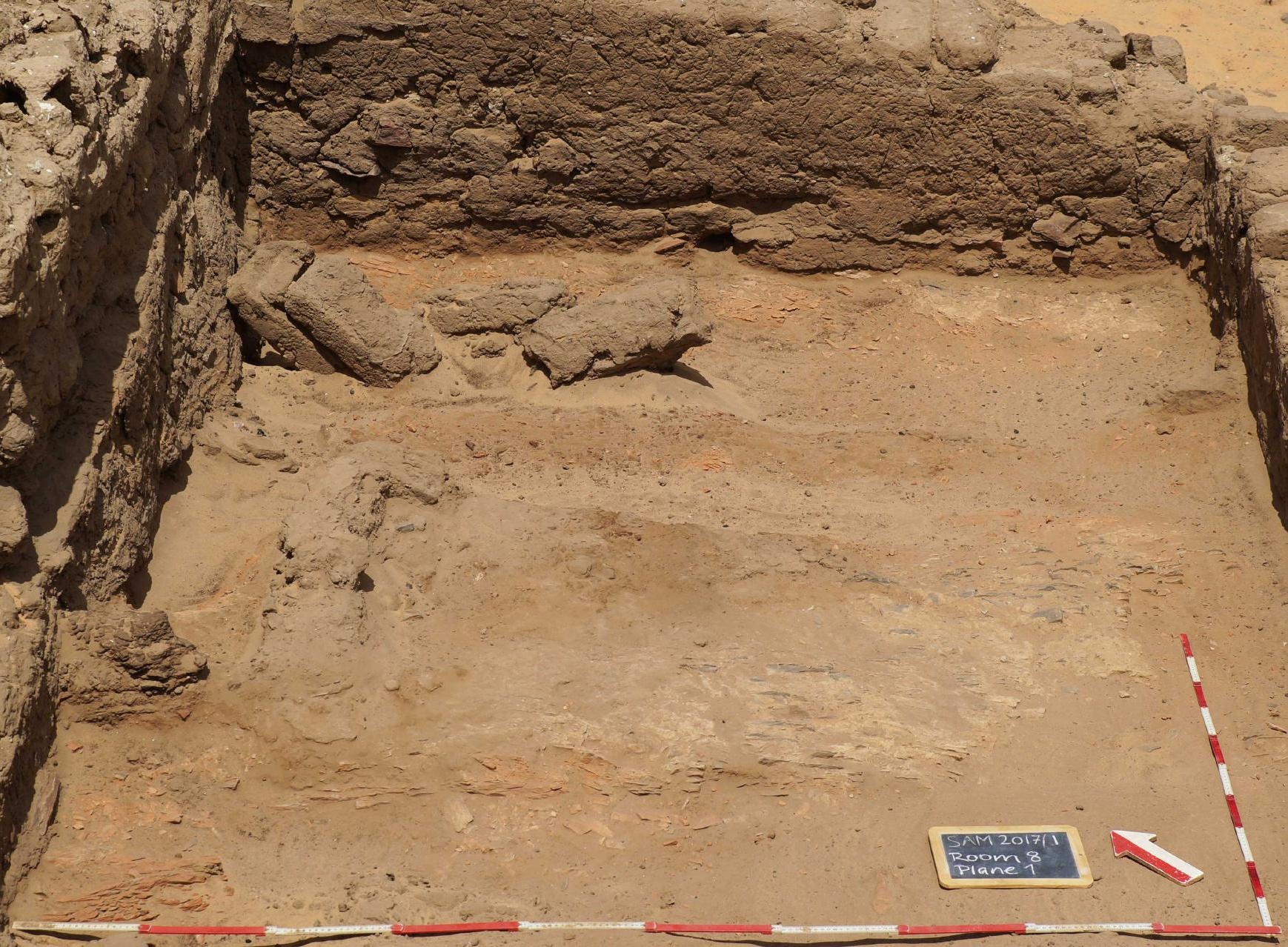




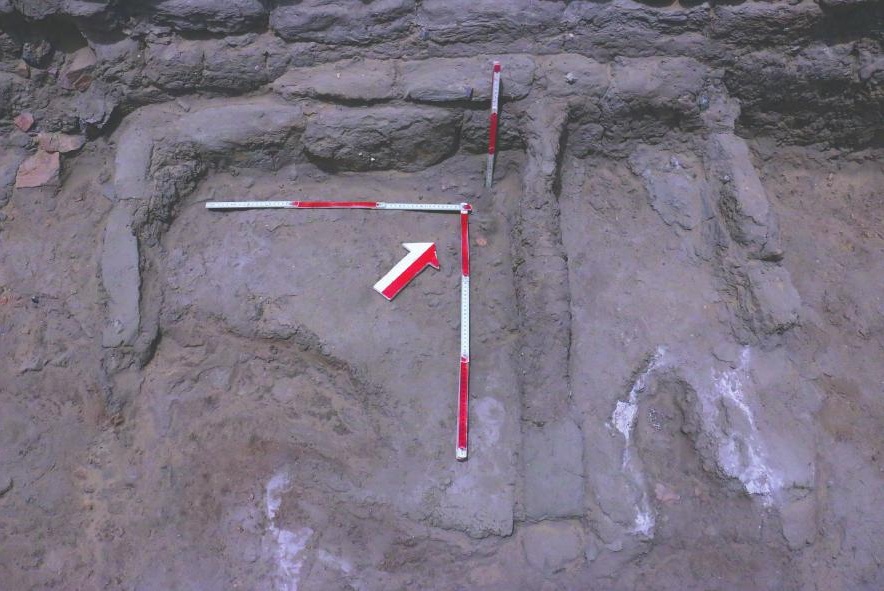




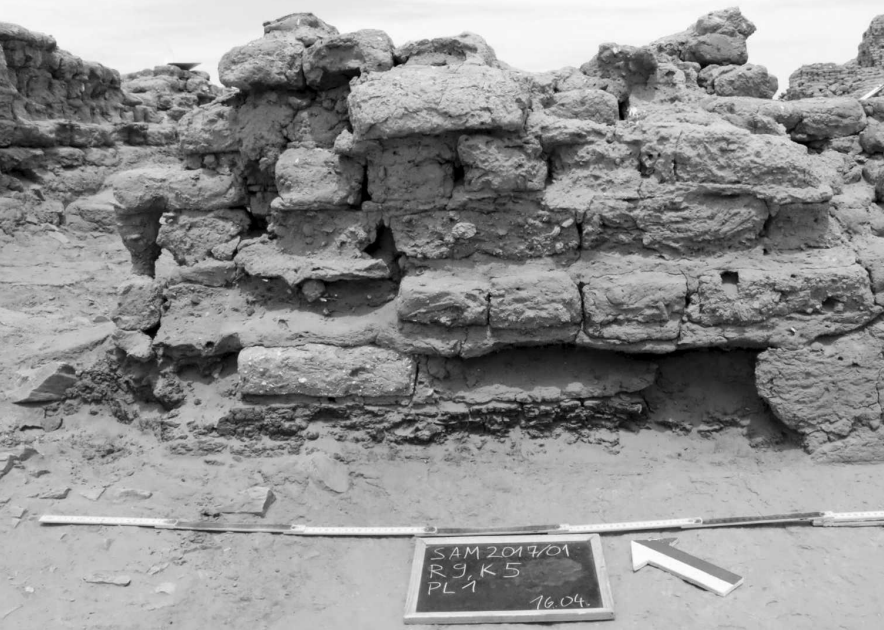



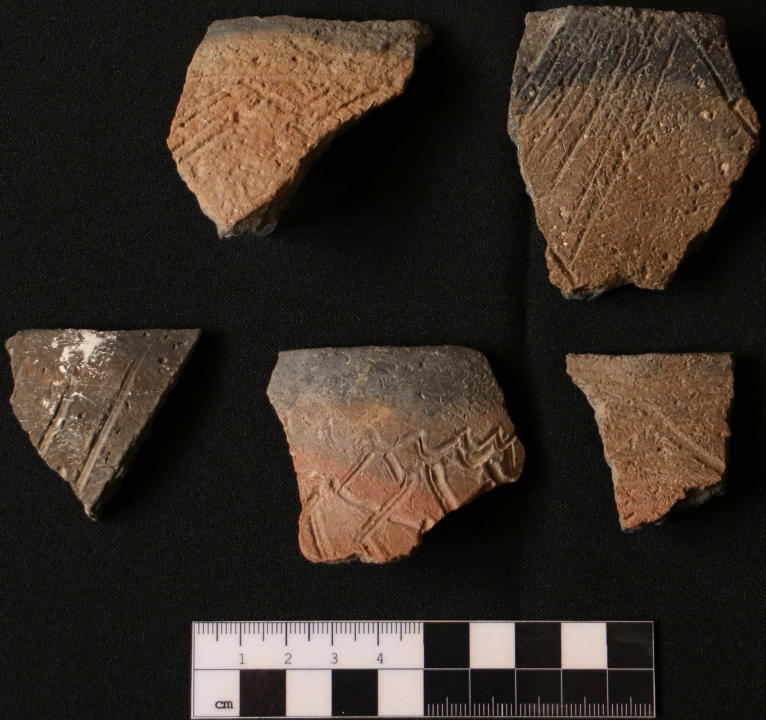


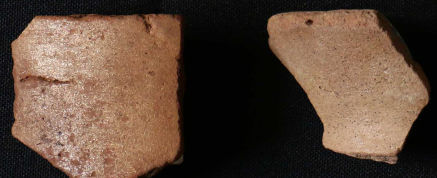

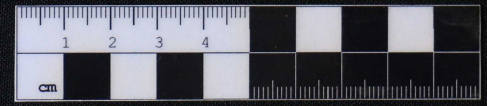




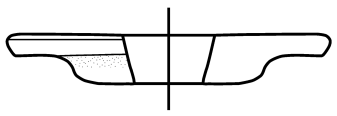

2017/01.000-001-020

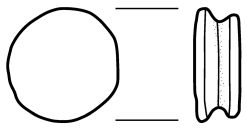

2017/01.000-001-031

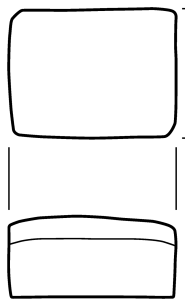

2017/01.000-001-006

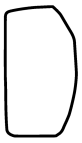

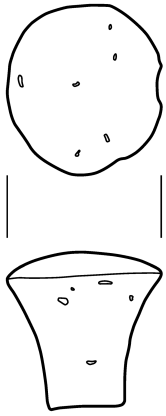

2017/01.000-001-019
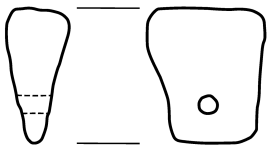

2017/01.000-001-040

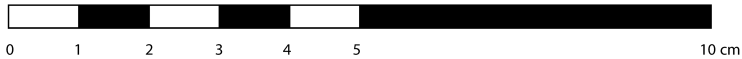



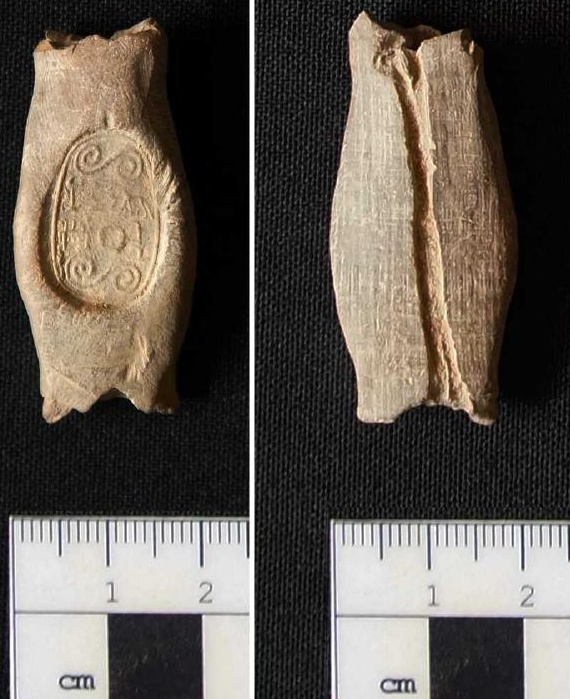


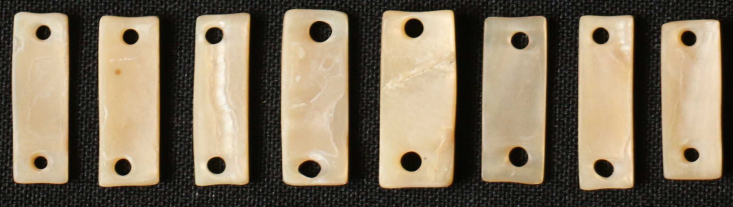

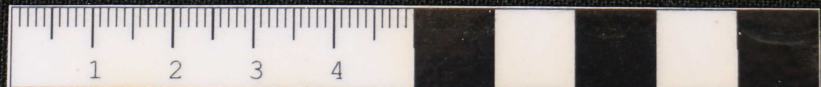




\section{rare 5}

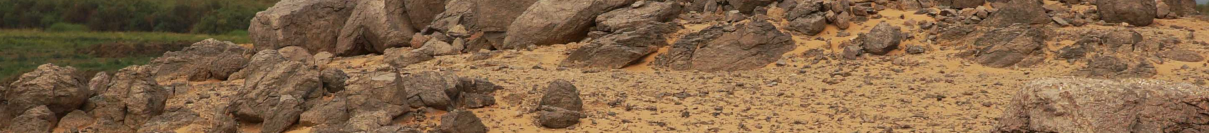

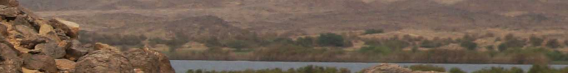

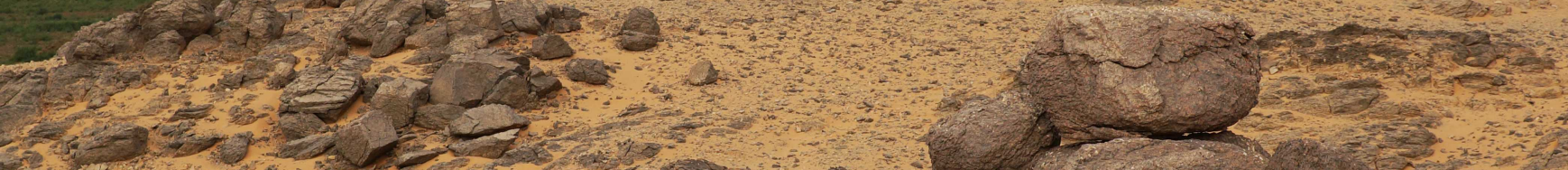

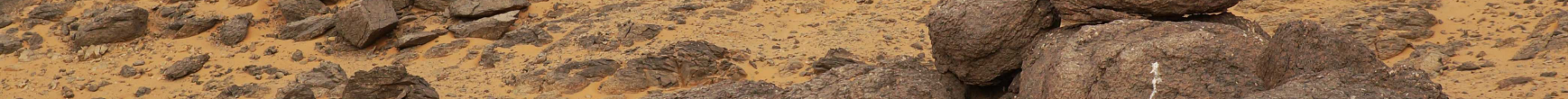

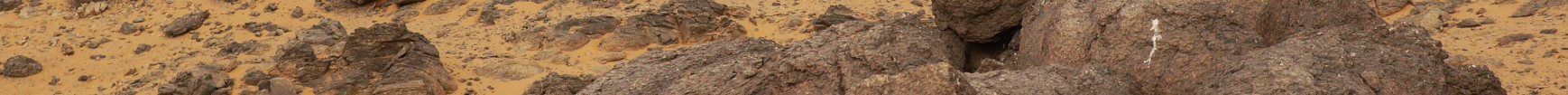

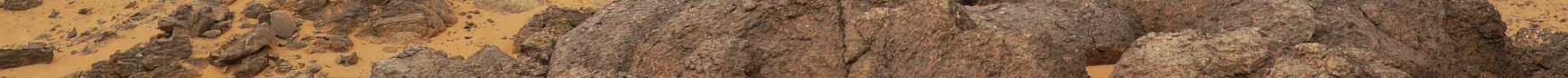

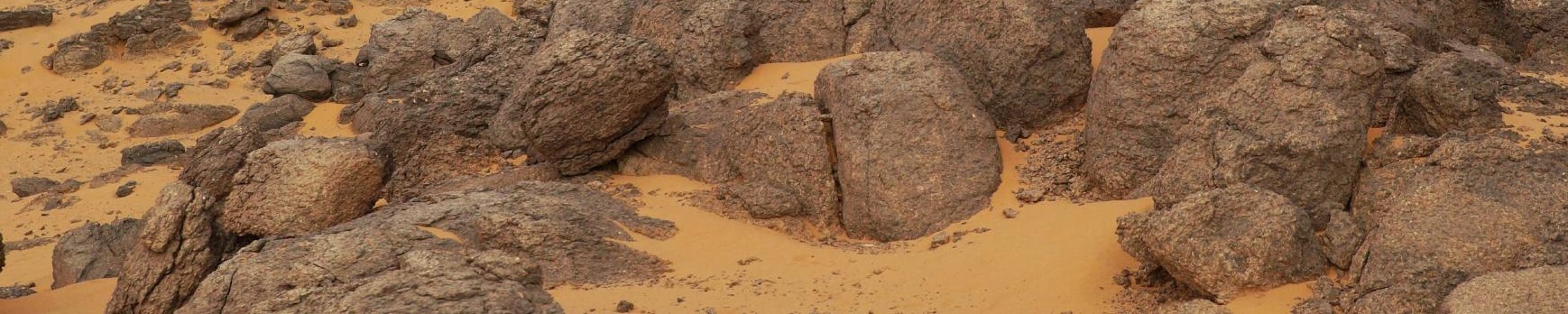




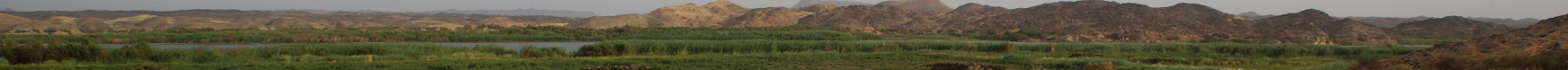

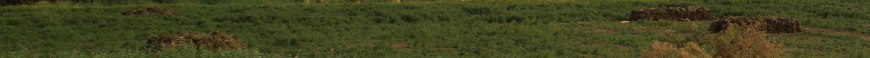

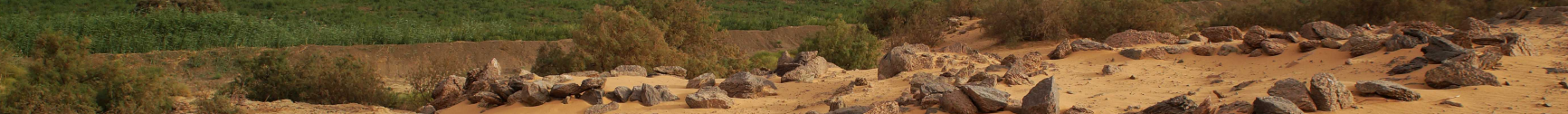

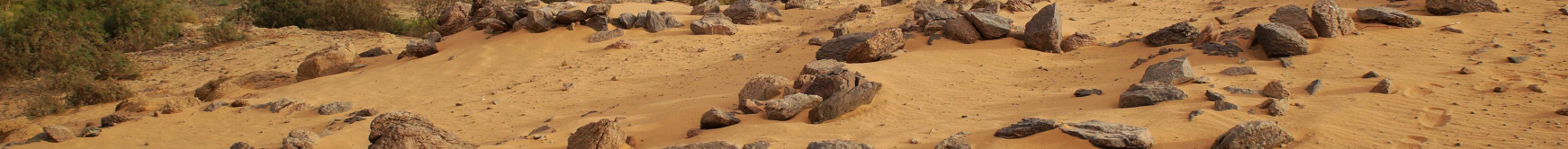

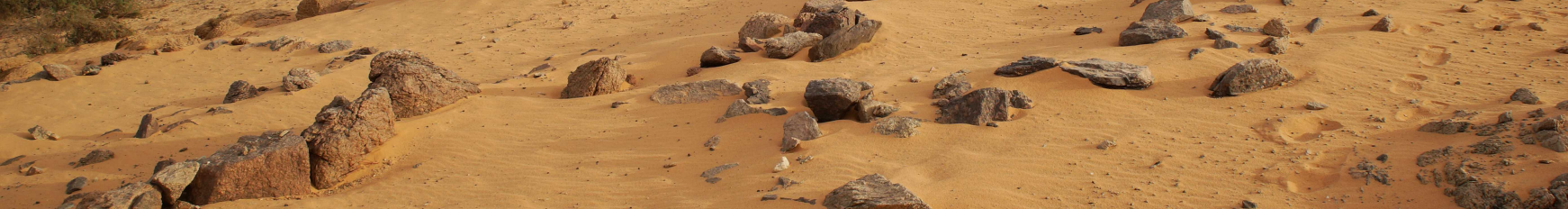

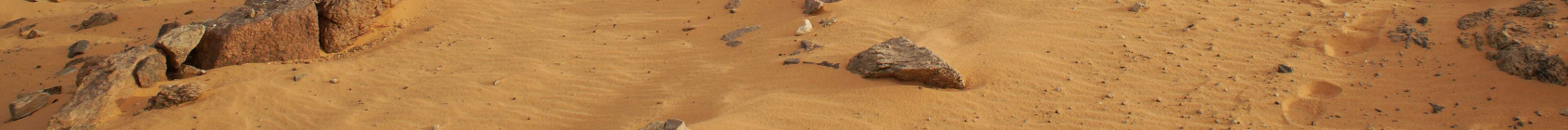
2. 